Review

\title{
The Recycling of Coal Fly Ash: A Review on Sustainable Developments and Economic Considerations
}

\author{
Amanda Qinisile Vilakazi ${ }^{1,2, *}$, Sehliselo Ndlovu ${ }^{1,2, *(\mathbb{C}}$, Liberty Chipise ${ }^{1,2,3}$ and Alan Shemi ${ }^{1,2}$ (I) \\ 1 School of Chemical and Metallurgical Engineering, University of the Witwatersrand, \\ Johannesburg 2050, South Africa; liberty.chipise@wits.ac.za (L.C.); alanshemi@yahoo.co.uk (A.S.) \\ 2 DSI/NRF SARChI: Hydrometallurgy and Sustainable Development, University of the Witwatersrand, \\ Johannesburg 2050, South Africa \\ 3 Department of Metallurgical Engineering, Manicaland State University of Applied Sciences, \\ Mutare 00263, Zimbabwe \\ * Correspondence: aqVilakazi@gmail.com (A.Q.V.); Sehliselo.Ndlovu@wits.ac.za (S.N.)
}

Citation: Vilakazi, A.Q.; Ndlovu, S.; Chipise, L.; Shemi, A. The Recycling of Coal Fly Ash: A Review on Sustainable Developments and Economic Considerations. Sustainability 2022, 14, 1958. https://doi.org/10.3390/su14041958

Academic Editors: Elena Rada

Marco Ragazzi, Ioannis Katsoyiannis, Elena Magaril, Paolo Viotti, Hussain H. Al-Kayiem, Marco Schiavon, Gabriela Ionescu and Natalia Sliusar

Received: 14 December 2021

Accepted: 12 January 2022

Published: 9 February 2022

Publisher's Note: MDPI stays neutral with regard to jurisdictional claims in published maps and institutional affiliations.

Copyright: (c) 2022 by the authors. Licensee MDPI, Basel, Switzerland. This article is an open access article distributed under the terms and conditions of the Creative Commons Attribution (CC BY) license (https:// creativecommons.org/licenses/by/ $4.0 /)$.

\begin{abstract}
The recycling and utilization opportunities for coal fly ash (CFA) have increased in the past two decades. However, limited commercialization of the material is still reported, while disposal and management remain major concerns. CFA utilization is currently commercially feasible in the building and construction industry. Other alternative uses that are being explored involve the extraction of valuable metals and the purification of wastewater. The CFA-produced adsorbent material utilized in wastewater purification processes should be able to generate water that meets the legal quality requirements for reutilization in alternative applications. On the other hand, in the recovery of metallic components such as smelter-grade alumina, high recovery and high purity products are only achievable through the processing of CFA using expensive and energy-intensive processes. Furthermore, most of the current CFA recycling processes tend to generate secondary solid residues (SSR), which can cause environmental pollution, thus requiring further downstream processing. In this context, this paper reviews and discusses current research on CFA recycling methods, challenges and opportunities associated with resource recovery from CFA, and the acceptability of the valueadded products, and it therefore proposes sustainable processes for CFA utilization. This review further suggests that to successfully compete with bauxite for production of smelter-grade alumina, other saleable value-added products such as $\mathrm{Ti}, \mathrm{Fe}$ and the REEs should be recovered by engineering an integrated process design. The generated SSR in each process must also be characterized, recycled and re-used to reduce waste production and advance the circular economy concept. The review concludes that for CFA to become considered as a more attractive commercial resource, there is need for its complete and holistic utilization in high volumes and in different applications to offset its low value.
\end{abstract}

Keywords: coal fly ash; environmental effects; sustainability; resource recovery; low-cost adsorbents; activation performance; process integration

\section{Introduction}

While coal is the primary energy resource in the world, coal-powered plants have been identified as the major source of $\mathrm{CO}_{2}$ emission due to the coal combustion process [1]. The consumption of energy from coal-based resources has also been revised to mitigate the effects of greenhouse gas emissions on climate change [1]. The development of "clean" coal combustion technologies has been realized through high-efficiency, low-emission (HELE) coal power generation. HELE technology aims to reduce coal consumption and $\mathrm{CO}_{2}$ emission as well as capture and store carbon emission. The technology is based on the concept that an increase in the maximum temperature of steam to supercritical levels increases electrical efficiency, which in turn lowers both coal consumption and flue gas emission [2]. Currently, Japan, Korea and China have implemented ultra-supercritical 
(USC) and advanced ultra-supercritical (AUSC) coal-powered plants [3,4]. In South Africa, the newly developed Medupe and Kusile power plants, with power generation capacities of $4764 \mathrm{MW}$ and $4800 \mathrm{MW}$, are built on supercritical (SC) pulverized systems [5]. The transformation to HELE requires reconstruction and upgrading of old power plants; thus, the advancement of this technology largely depends on strong financial support, subsidies and a sound policy framework [4].

To meet the standards for "clean air", a number of international agreements and regulations are being enforced in order to move towards renewable energies such as windpower, solar energy and bioenergy. When renewable energy displaces coal, it essentially eliminates the emissions of both air pollutants and greenhouse gases, thus providing benefits to air quality, public health and climate change. In countries such as South Africa, which is heavily dependent on coal, it will take a significant amount of time before an efficient and affordable transformation is implemented [6]. More than $80 \%$ of the South African energy mix includes sources from coal [7]. With an ever-increasing demand for energy, elimination of the coal component in the energy mix in order to move towards renewable energy still remains a huge challenge.

Coal fly ash (CFA) is a major component of coal combustion waste (CCW) produced in large quantities. Statistics on CCW commercialization differ from country to country. In South Africa, $>50$ million tons of CCW is produced annually, while close to $10 \%$ is re-used, primarily in the building and construction industry $[7,8]$. By contrast, other industrialized countries such as the USA and countries in Europe have much higher utilization rates. According to European Coal Combustion Products Association, Europe produced close to 40 million tonnes of CCW in 2016 and re-used more than $90 \%$ in the construction industry and for reclamation [9]. In the same year, the USA produced approximately 107 million tonnes of CCW and re-used close to $60 \%$ [10]. In 2020, their total CCW was reduced to 40 million tonnes, while close to $58 \%$ was re-used [11]. The building and construction industry contributes significantly to the recycling of CFA, since it is utilized directly as raw resource or additive material. However, the quantities disposed remain a major management concern.

CFA is also a potential low-cost adsorbent material, either through direct utilization or functionalized synthesis [12,13]. It is also identified as an alternative source for metallurgical recovery of high-purity products such as alumina [14,15]. However, CFA is a complex material to beneficiate; therefore, the economic and environmental impact on process design should be ascertained. This paper seeks to review and discuss current research on CFA recycling methods, the acceptability of the value-added products, challenges and opportunities, and it therefore proposes sustainable processes for CFA utilization.

\section{CFA Waste Management Techniques}

The global classification of CCW as hazardous waste has intensified CCW disposal constraints, as coal power-houses are required to comply with the legislation and regulations on waste maintenance. The disposal of coal combustion by-products in landfills and ash ponds is the primary management technique. However, the disposal facilities are running out of storage space due to the large quantities of CCW produced compared to the utilization rate $[1,8,16]$. In the wet disposal technique, CCW is mixed with water and transported as slurry to the dumping site (through pipes) where over time the water is allowed to drain as the ash settles. This process results in groundwater contamination due to leaching of toxic heavy metals. Thus, the installation of liner systems is mandatory for water quality monitoring. Additionally, the vast amount of water needed for the ash slurry is a concern due to high levels of water stress in the world [8]. The dry disposal technique results in air pollution from the fine ash particles during transportation as well as at the dumping site. These disposal techniques are not eco-friendly, and they tend to be expensive to maintain [6,8]. It is therefore imperative that other sustainable techniques of managing CFA be developed. 


\section{CFA Formation, Physical and Chemical Characteristics, and Mineralogy}

\subsection{CFA Formation}

In the coal combustion process, the pulverized coal is burned to generate electricity at $>1400{ }^{\circ} \mathrm{C}$ furnace temperatures. The organic matter is combusted, captured by the flue gas desulfurization scrubber, adsorbed and recovered as gypsum (FGD gypsum), while the exhaust gas, mainly $\mathrm{CO}_{2}$, is released to the atmosphere. The minerals are oxidized, decomposed and fused, generating large quantities of by-product material known as CCW [17]. The hollow cenospheric ash particles are formed once the exhaust gases evolve. This ash particles are generally spherical in shape $[17,18]$. However, irregular and oval ash particles are also observed [19]. In the post-combustion zone, the ash particles sustain their equilibrium shape, and the rapid cooling of these molten particles will form coal fly ash (CFA) $[17,18]$. The morphology of CFA cenospheric ash particles is shown in Figure 1.

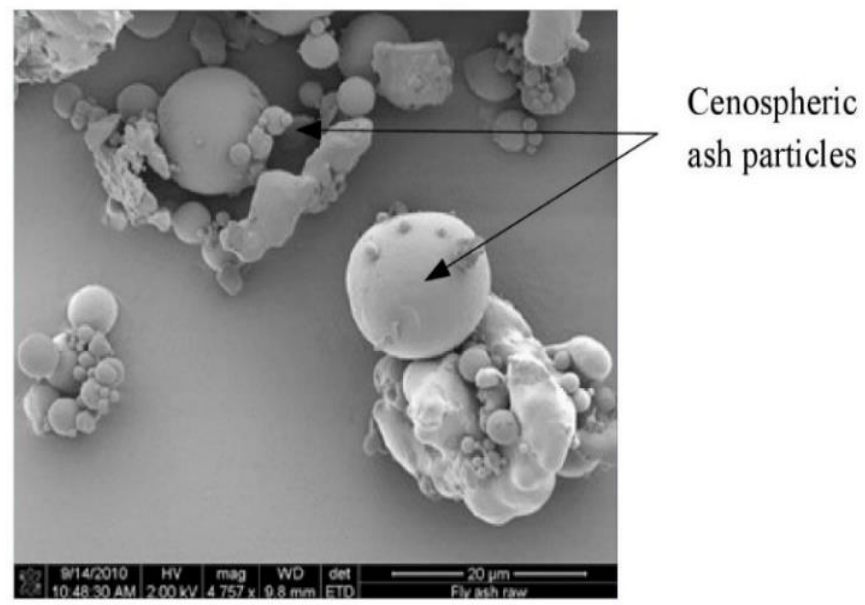

Figure 1. The structure of Eskom CFA showing the surface morphology of CFA cenospheric ash particles $(\times 4757)[20]$.

The first CCW content collected at the bottom of the boiler has coarse particles and is thus called coal bottom ash (CBA). The remaining ash content is CFA, which is much lighter in weight and is carried into the electrostatic precipitator [17]. Depending on the design of the combustion system, other CCW materials such as fluidized bed combustion (FBC) ash and boiler slag are also collected separately. In South Africa, CFA accounts for more than $80 \%$ of the CCW content generated during the coal combustion process.

\subsection{CFA Physical and Chemical Characteristics}

The properties of CFA are largely influenced by the parent coal source, coal combustion conditions, post-combustion conditions and the emission control technology [21]. CFA is an alkaline material with a $\mathrm{pH}$ in the range of 8.5-11.5. It consists of very fine spherical particles that can range from 1-100 $\mu \mathrm{m}$ in size, and it has low to medium bulk density and fine texture [22]. The evaluation of CFA quality is based on its LOI (loss on ignition) value, moisture content and sulphur trioxide. The LOI test is a method for estimating the unburned carbon content of CFA, and it varies depending on combustion conditions. This property is generally used by coal-power plants to assess the success of the coal combustion process.

The major chemical components in $\mathrm{CFA}$ are $\mathrm{SiO}_{2}$ and $\mathrm{Al}_{2} \mathrm{O}_{3}$, with minor quantities of $\mathrm{Fe}_{2} \mathrm{O}_{3}, \mathrm{CaO}$ and $\mathrm{TiO}_{2}$ (Table 1). The American Society of Testing Materials (ASTM C618) has classified CFA according to its chemical composition as Class $C$ and Class F. The Class C CFA is classified as the high-lime-content CFA and is regarded as cementitious. Class F has low lime content and is regarded as pozzolanic [23,24]. This classification is extensively used in the building and construction industry. According to the South African Coal Fly Ash Association (SACAA), South Africa only produces class F CFA [25]. In contrast, India generates power from bituminous coal, thus producing Class C CFA [26]. 
However, coal may also be blended to maximize the generation efficiency or to improve the power plant environmental performance; therefore, most CFA do not fully fit into this classification.

Table 1. Major chemical composition of CFA.

\begin{tabular}{ccccc}
\hline Component & China $^{\mathbf{a}}$ & India $^{\mathbf{b}}$ & USA $^{\mathbf{c}}$ & South Africa $^{\mathbf{d}}$ \\
\hline $\mathrm{SiO}_{2}$ & $31.4-60.0$ & $50.2-59.7$ & $37.8-58.5$ & $49.92-56.29$ \\
$\mathrm{Al}_{2} \mathrm{O}_{3}$ & $11.2-55.0$ & $14.0-32.4$ & $19.1-28.6$ & $27.21-31.52$ \\
$\mathrm{Fe}_{2} \mathrm{O}_{3}$ & $1.5-19.3$ & $2.7-14.4$ & $6.8-25.5$ & $2.58-5.91$ \\
$\mathrm{CaO}$ & $0.8-31.0$ & $0.6-2.6$ & $1.4-22.4$ & $4.80-9.47$ \\
$\mathrm{TiO}_{2}$ & $0.2-1.5$ & $0.2-0.7$ & $1.1-1.6$ & $1.39-2.25$ \\
$\mathrm{Na}_{2} \mathrm{O}$ & $0.2-2.4$ & $0.5-1.2$ & $0.3-1.8$ & $0.03-0.81$ \\
$\mathrm{SO}_{3}$ & $0.1-3.5$ & - & $0.1-2.1$ & $0.05-4.78$ \\
$\mathrm{MgO}$ & $0.4-4.8$ & $0.1-2.1$ & $0.7-4.8$ & $1.47-2.69$ \\
$\mathrm{P}_{2} \mathrm{O}$ & $0.3-1.5$ & $0.1-0.6$ & $0.1-0.3$ & $0.45-0.90$ \\
$\mathrm{MnO}$ & $0.05-0.06$ & $0.5-1.4$ & - & - \\
$\mathrm{LOI}$ & $2.4-18.3$ & $0.5-5.0$ & $0.2-11.0$ & $1.54-7.81$ \\
\hline
\end{tabular}

a $[23],{ }^{\mathrm{b}}[24],{ }^{\mathrm{c}}[25],{ }^{\mathrm{d}}[26],-$ Not available.

The trace concentration of valuable constituents in CFA such as the rare earth elements (REEs) has also been quantified (Table 2) and thus could add significant value in a full-scale commercial utilization if economically extracted. The REEs are described as a group of 17 elements which include the lanthanide series (La-Lu), yttrium (Y) and scandium (Sc). Compared to their primary ore deposits such as bastnaesite, monazite and xenothime, CFA is concentrated with both light rare earth elements (LREEs) and heavy rare earth elements (HREEs) $[27,28]$. The trace concentration of the radionuclides such as uranium, thorium and radium and the heavy toxic elements boron, chromium, lead, mercury and arsenic are also quantified [29]. Most of the trace elements remain within the residue in the leaching process, as they do not occur in significant amounts to warrant economic extraction. However, potential leaching and concentrations in soil and dams can still result in significant environmental pollution [30].

Table 2. The average concentration of REEs in different CFA.

\begin{tabular}{ccccc}
\hline $\begin{array}{c}\text { Element } \\
(\mathbf{m g} / \mathbf{k g})\end{array}$ & $\begin{array}{c}\text { Junga Power } \\
\text { Plant, China }^{\mathbf{a}}\end{array}$ & $\begin{array}{c}\text { Tutuka Power } \\
\text { Station, RSA }\end{array}$ & $\begin{array}{c}\text { Polish Power } \\
\text { Plant, Poland }^{\text {c }}\end{array}$ & $\begin{array}{c}\text { Kentucky Power } \\
\text { Plant, USA d }^{\mathbf{d}}\end{array}$ \\
\hline $\mathrm{Sc}$ & 23.0 & 26.50 & 30.00 & 42.39 \\
$\mathrm{Y}$ & 54.2 & 64.87 & 48.50 & 107.64 \\
$\mathrm{La}$ & 104.3 & 91.36 & 59.60 & 108.25 \\
$\mathrm{Ce}$ & 178.0 & 182.42 & 123.20 & 212.20 \\
$\mathrm{Pr}$ & 21.5 & 19.72 & 13.74 & - \\
$\mathrm{Nd}$ & 72.5 & 71.76 & 53.50 & 88.13 \\
$\mathrm{Sm}$ & 13.5 & 14.38 & 11.10 & 18.68 \\
$\mathrm{Eu}$ & 2.39 & 6.65 & 2.40 & 3.88 \\
$\mathrm{Gd}$ & 11.7 & 12.62 & 8.93 & 18.81 \\
$\mathrm{~Tb}$ & 1.83 & 2.68 & 1.50 & 2.95 \\
$\mathrm{Dy}$ & 10.76 & 11.91 & 8.34 & 17.46 \\
$\mathrm{Ho}$ & 2.13 & 2.35 & 1.77 & 3.54 \\
$\mathrm{Er}$ & 6.17 & 6.65 & 4.53 & 9.88 \\
$\mathrm{Tm}$ & 0.56 & 0.95 & 0.75 & 1.40 \\
$\mathrm{Yb}$ & 3.93 & 6.5 & 4.55 & 8.82 \\
$\mathrm{Lu}$ & 0.55 & 0.93 & 0.68 & 1.31 \\
\hline
\end{tabular}

${ }^{\mathrm{a}}[26],{ }^{\mathrm{b}}[31],{ }^{\mathrm{c}}[32],{ }^{\mathrm{d}}[33]$.

\subsection{CFA Mineraslogy}

The phases in CFA can be classified as crystalline and non-crystalline. The noncrystalline phase (also known as amorphous phase), with no specific chemical formula, constitutes more than $50 \%$ of the CFA composition, and it is often more complex than the 
crystalline phase. However, it is the most reactive phase in acidic and alkaline solutions [34]. The basic chemical composition of the non-crystalline phase consists mostly of oxides such as $\mathrm{SiO}_{2}, \mathrm{Al}_{2} \mathrm{O}_{3}, \mathrm{Fe}_{2} \mathrm{O}_{3}, \mathrm{TiO}_{2}, \mathrm{MgO}$ and $\mathrm{CaO}$ [35].

The crystalline phase is well-defined and accounts for the balance of the CFA composition. The major minerals that make up the crystalline phase are refractory mullite $\left(3 \mathrm{Al}_{2} \mathrm{O}_{3} \cdot 2 \mathrm{SiO}_{2}\right)$ and $\alpha$-quartz $\left(\mathrm{SiO}_{2}\right)$. These phases are reactive only at high-temperature and high-pressure conditions [34,36]. There are also a few Fe crystalline phases of magnetite $\left(\mathrm{Fe}_{3} \mathrm{O}_{4}\right)$, hematite $\left(\alpha-\mathrm{Fe}_{2} \mathrm{O}_{3}\right)$ and maghemite $\left(\gamma-\mathrm{Fe}_{2} \mathrm{O}_{3}\right)$, and these are known to be quite reactive in acidic solutions [20,37]. Calcium has also been quantified in several phases; primarily, it is quantified as lime $(\mathrm{CaO})$. However, due to several post-combustion conditions such as weathering, $\mathrm{CaO}$ can undergo transformation into gypsum and ettringite [21,38].

While the distribution of the major compositions in CFA is clear, the distribution of the REEs is complex. They are said to occur as dispersed metal oxide nano-sized particles on the surface of CFA. Some authors suggest that REEs are enclosed or encapsulated in aluminosilicate glass (amorphous phase), while others claim that they are associated with Fe-oxide and calcium fractions [39-41].

\section{Direct Utilization of CFA}

The direct utilization of CFA occurs largely through the building and construction industry in the production of cement and concrete, including bricks and blocks [13,42-44]. In addition to this outstanding performance, CFA can also be activated through functionalised synthesis of geopolymers and zeolites [45]. Considerable research is also available on the utilization of CFA as a cheap alternative remediation for wastewater purification and adsorption of gaseous pollutants. However, in most of these processes, CFA is used in low quantities, which does not significantly impact the large amount produced annually. An ideal sustainable process should not only utilize the high-volume of CFA, but should also have a high-value return to ensure sustainability [30].

\subsection{Building and Construction Material}

The recycling of CFA in the construction industry is well-established and guided by utilization rules and regulations [46]. The Eskom power utility in RSA has reported that when 25 million tonnes of CFA is produced annually, only 1.2 million tonnes is sold to the construction industry [7]. A number of organisations such as Ulula Ash and Ash Resource Limited are part of the Cement and Concrete Product Manufacturing Industry, and they supply CFA on a commercial scale. Ulula Ash is obtained directly from Kriel power plant through a conveyer system, beneficiated and sold to the market as class $S$ (classified, $>50 \mu \mathrm{m}$ ) fly ash and Class $\mathrm{N}$ (un-classified, $>50 \mu \mathrm{m}$ ) fly ash. Ash Resources Limited beneficiates CFA into Durapozz and Pozzfill material directly from Lethabo and Kendal power stations [47]. These materials have been used in the construction of wellknown projects such as the Katse Dam in Lesotho, the Burj Khalifa in Dubai and the Maputo-Katembe bridge in Mozambique [48].

\subsubsection{Cement and Concrete}

Concrete is made up of three essential components: water (used for curing), Portland cement, and aggregate (rock, sand or gravel). Cement acts as a binder material, and thus, the quality of concrete mainly depends on the water and cement ratio (0.3-0.6) [49]. When CFA is added into the mix, it acts as a supplementary cementing material, thus reducing the cost of production and carbon footprint. The formation of this supplementary material using CFA involves the reaction of free calcium hydroxide $\left(\mathrm{Ca}(\mathrm{OH})_{2}\right)$ with CFA, forming additional hydrating calcium silicate (Equations (1) and (2)). This reaction improves long-term strength, increases workability, and reduces heat of hydration and water demand $[13,49]$. The commercial dosage of CFA in concrete is regulated by a number of standards, which range from 5-35\%. In South Africa, cement production accounts for approximately $90 \%$ of recycled CFA and is certified by South Africa National Standards 
(SANS) 50197-1:2000. CEMII/A-V contains 6-20\% CFA, and CEMII/B-V contains 21-35\% CFA [50]. Other standards include the American Standard ASTMC 595, China National Standard GB1344-1999 and the Bureau of Indian Standards.

$$
\begin{gathered}
\text { Cement reaction: } \mathrm{C}_{3} \mathrm{~S}+\mathrm{H} \rightarrow \mathrm{CSH}+\mathrm{CaOH}_{2} \\
\text { Pozzolanic reaction: } \mathrm{C}_{3} \mathrm{~S}+\mathrm{H} \rightarrow \mathrm{CSH}+\mathrm{CaOH}_{2}
\end{gathered}
$$

High-volume fly ash concrete (HVFC) is the highest achievement in cement replacement with more than 50\% CFA. The development of this dosage is still on the experimental stage; thus, it is not commercially regulated [51,52]. Some of the challenges with HVFC include the reduction in rate of strength development, the final strength and early age strength. These shortcomings have hindered its application on a large scale [53].

\subsubsection{Bricks and Blocks}

Clay and shale are the primary materials used to manufacture bricks either by firing or cementing process. The conventional kiln firing process involves mixing the clay with water into desired shapes, followed by drying and firing in a high-temperature kiln $\left(900-1000{ }^{\circ} \mathrm{C}\right)$. This process is energy-intensive and emits greenhouse gases. The cementing process entails mixing and drying at room temperature; thus, it is not energy intensive. However, ordinary Portland cement (OPC) is added for high strength [30]. The shortage of natural resources has placed major restrictions onto clay bricks production, thus causing a shift towards eco-friendly building materials such as fly ash. Bricks made from fly ash are attractive due to their light weight, uniform size and high comprehensive strength [54]. Furthermore, replacing clay with CFA increases the yield of a cement kiln. Eskom, South Africa, CFA has been a successful key component in brick and block manufacturing for companies such as Inka Bricks, Big Sky Bricks and Rand Bricks [7]. Sasol (Pty) Limited South Africa also supply fly ash for Mr. Brick manufacturing company for production of fly-ash-based hollow, maxi and cement stock $[55,56]$. In China, permeable bricks and hollow blocks are also manufactured [53].

\subsubsection{Back Fillings}

Backfill technology has become an integral part of efficient underground mining operations. This has led to a reduction in disposal of secondary materials as well as provision of economic engineering materials. This application can potentially mitigate illegal underground mining and also improves safety after mine closure [57]. Backfilling with CFA can act as a soil rehabilitator, ameliorator of wastewater (e.g., AMD), void filler and engineering material. The pozzolanic binders, such as cement, are expensive compared to CFA. However, small quantities of cement are required to improve cohesion and increase the shear strength and permeability. The ground injection with CFA has been identified as a potential AMD remediation technique, as it can neutralize AMD and also prevent contact between water and pyrite [58,59]. The key issue, however, is the cost of CFA transportation from power plants to the mining site. This option is only attractive for those operations located near coal-powered plants.

Besides backfilling of underground mines, open cast mine filling using CFA can be employed as a land reclamation method. CFA can resemble natural soil in its chemical and physical properties. Therefore, the addition of CFA in soil improves soil texture, increases the soil water-holding capacity, bulk density and electrical conductivity and adjusts the soil $\mathrm{pH}$ [60-62].The agricultural lands located close to the coal-power stations could benefit more, as they are mostly acidic due to large pollutions in mining sites $[13,48]$. In the United States, Coal Creek Station in collaboration with Great River Energy successfully completed a land reclamation project for on-site power station project [63]. It is also noted that, although CFA is similar to soil, it contains toxic elements such as arsenic, chromium and selenium, which have the ability to affect water quality and crop yield [19]. 


\subsubsection{Alkali Activation and Geopolymerization}

The reaction between a strong alkaline solution and an amorphous aluminosilicate source results in geopolymer material [64]. In the construction industry, the synthesis of geopolymer material is aimed at $100 \%$ CFA utilization compared to blended cement or high-volume fly ash concrete (HVFC) (Table 3). In this process, CFA is reacted with sand aggregate material and an alkaline solution with no cement additive. The alkaline solution is made of sodium salts $\left(\mathrm{NaOH} / \mathrm{NaSiO}_{2}\right.$ and $\left.\mathrm{H}_{2} \mathrm{O}\right)$ or potassium salts $\left(\mathrm{KOH} / \mathrm{KSiO}_{2}\right.$ and $\mathrm{H}_{2} \mathrm{O}$ ) of different concentrations (8-14 M) [45,64,65]. In the conventional process using OPC cement, an alkaline solution acts as an activator instead of water. Geopolymer concrete is the ideal concrete material with physical properties superior to OPC concrete. The environmental benefits of using geopolymers are reduction in $\mathrm{CO}_{2}$ emission, high-volume utilization of CFA and reduced price, as CFA-based geopolymer concrete can be 10-30\% cheaper than OPC concrete $[48,66,67]$. Table 3 summarizes the different CFA replacement materials used in the building and construction industry.

Table 3. The replacement of cement with CFA in different material.

\begin{tabular}{ccccc}
\hline Parameters & OPC & Blended Cement & HVFC & Geopolymer \\
\hline CFA replacement & $0 \%$ & $20-35 \%$ & $50 \%$ & $100 \%$ \\
Binder & Cement & CFA + Cement & CFA + Cement & CFA \\
Mixer & $\mathrm{H}_{2} \mathrm{O}$ & $\mathrm{H}_{2} \mathrm{O}$ & $\mathrm{H}_{2} \mathrm{O}$ & $\begin{array}{c}\text { Alkaline solution } \\
\text { Hydration and } \\
\text { Activation process } \\
\text { (curing) }\end{array}$ \\
$\begin{array}{c}\text { Thermal activation } \\
\text { energy }\end{array}$ & Nydration & Hydration & Hydration & geopolymerization \\
Thermal curing \\
$\left(60-90^{\circ} \mathrm{C}\right)$
\end{tabular}

Although geopolymers provide alternative sustainability, only a few projects based on geopolymer materials exist. It has been observed that geopolymer materials lack uniformity during synthesis due to variation in CFA composition, and thus, test trials are necessary, as the quality of CFA is not often uniform. The material also consumes large quantities of alkaline solution, which may solidify to unwanted rock-like material $[68,69]$. Sasol (Pty) Limited has patented a process that synthesizes polymer using secondary materials such as CFA. In this process, CFA is mixed with cement and polymer to form light-weight and dense material. The houses built in Cosmo City, South Africa, are made from this secondary materials [70]. This project is in collaboration with the Murray and Robertson (M\&R) and AfriSam private companies [71].

\subsection{Environmental Remediation}

Although CFA has been largely categorized as waste material, it has been observed to have environmental benefits in pollution control and environmental sustainability. Similar to volcanic ash, CFA is also an aluminosilicate material and thus has three similar properties to zeolite: adsorption, catalytic behaviour, and ion exchange capacity [72]. Zeolites are micro-porous materials with $\mathrm{SiO}_{4}$ and $\mathrm{AlO}_{4}$ tetrahedral crystal arrangement and constitute either group I or group II elements as counter ions. Although they occur naturally as minerals (stilbite, analcime and clinoptilolite), they can also be synthesized to meet specific industrial applications [73]. On a commercial scale, zeolites compete with bentonite, gypsum and silica sand in various applications such as soil amendment, water treatment and purification, oil and grease absorbent, gas absorbent, fungicide or pesticide carrier [74] The replacement of natural zeolite with CFA could conserve primary resources and reduce carbon footprint and the cost of mining processes.

\subsubsection{Wastewater Purification}

Water scarcity due to climate change and population growth has been a major concern around the world, and thus water conservation methods are necessary [75]. Coal-powered 
plants are among major consumers and polluters of water. Acid mine drainage (AMD) is the common wastewater which results from sulphur oxidation in sulphide minerals (Equations (3)-(5)) when exposed to water and air, either during mining operations or as a result of natural weathering after mining operations [76]. AMD is characterized by low $\mathrm{pH}(2-4)$, high salt content $\left(\mathrm{SO}_{4}{ }^{2-}\right)$ and a high level of heavy metals such as iron, aluminium, manganese and zinc. This impacted water does not meet the discharge limit to the environment and thus pollutes rivers and underground water.

$$
\begin{gathered}
2 \mathrm{FeS}_{2(\mathrm{~s})}+7 \mathrm{O}_{2(\mathrm{aq})}+2 \mathrm{H}_{2} \mathrm{O}_{(\mathrm{l})} \rightarrow 2 \mathrm{Fe}_{(\mathrm{aq})}^{2+}+4 \mathrm{H}_{(\mathrm{aq})}^{+}+4 \mathrm{SO}_{4(\mathrm{aq})}^{2-} \\
4 \mathrm{Fe}_{(\mathrm{aq})}^{2+}+4 \mathrm{H}_{(\mathrm{aq})}^{+}+\mathrm{O}_{2(\mathrm{~g})} \rightarrow 4 \mathrm{Fe}_{(\mathrm{aq})}^{3+}+2 \mathrm{H}_{2} \mathrm{O}_{(\mathrm{l})} \\
\mathrm{FeS}_{2(\mathrm{~s})}+14 \mathrm{Fe}_{(\mathrm{aq})}^{2+}+8 \mathrm{H}_{2} \mathrm{O}_{(\mathrm{l})} \rightarrow 15 \mathrm{Fe}_{(\mathrm{aq})}^{2+}+2 \mathrm{SO}_{4(\mathrm{aq})}^{2-}+16 \mathrm{H}_{(\mathrm{aq})}^{+}
\end{gathered}
$$

The common commercially available technologies for treatment of mine-impacted water are chemical neutralization techniques such as high-density sludge (HDS) precipitation and reverse osmosis (RO). Reverse osmosis produces potable water quality. However, the process generates brine solution as a waste by-product. The HDS process is relatively cheaper than RO. However, the process does not generate potable water and has a high sulphate concentration that remains untreated. The voluminous sludge produced as a by-product is difficult to dispose of due to scarcity of land as well as the possibility of redissolution of metals. These current treatment options are expensive and energy-intensive; therefore, they are regarded as short-term solutions and remain unsustainable $[76,77]$. CFA has been identified as one of the cheapest, most environmentally friendly and most innovative alternatives in the treatment of industrial effluent and mine wastewater.

\section{Neutralization and Precipitation of Metal Ions}

Limestone is commercially used to neutralize and precipitate metal ions from wastewater [77]. CFA also contains the basic oxides such as $\mathrm{Al}_{2} \mathrm{O}_{3}, \mathrm{Fe}_{2} \mathrm{O}_{3}$ and $\mathrm{CaO}$, which integrates properties such as precipitation, acid neutralization and adsorption to recover sulphates and metal ions when in contact with wastewater, as shown in Equations $(6)-(8)[77,78]$. For example, Gitari et al., (2006) [79] treated the AMD solutions with $\mathrm{pH} 2-3$ and high electrical conductivity $(10-11 \mathrm{mS} / \mathrm{cm})$ and observed that at CFA:AMD ratio of 1:3, the AMD solutions are neutralized to $\mathrm{pH} 9-10$ after $180 \mathrm{~min}$ with a decrease in electrical conductivity between 2 and 4 . The neutralization process was found to depend on three important factors, CFA: AMD ratio, reaction contact time, and the chemistry of the AMD solution [79].

$$
\begin{gathered}
\mathrm{Ca}^{2+}+\mathrm{SO}_{4}^{2-}+2 \mathrm{H}_{2} \mathrm{O} \rightarrow \mathrm{CaSO}_{4} \cdot 2 \mathrm{H}_{2} \mathrm{O}_{(\mathrm{s})} \\
\mathrm{Me}^{3+}+3 \mathrm{H}_{2} \mathrm{O} \rightarrow \mathrm{Me}(\mathrm{OH})_{3(\mathrm{~S})}+3 \mathrm{H}^{+} \\
\mathrm{X}^{+}+3 \mathrm{Me}^{3+}+2 \mathrm{SO}_{4}^{2-}+6 \mathrm{OH}^{-} \rightarrow \mathrm{XMe}_{3}\left(\mathrm{SO}_{4}\right)_{2}(\mathrm{OH})_{6(\mathrm{~s})}
\end{gathered}
$$

In the AMD treatment process, it has been found that Fe, Mn and $\mathrm{Zn}$ precipitate at the $\mathrm{pH}$ of their minimum solubility $[78,79]$. Several mechanisms are also observed in the reduction of $\mathrm{SO}_{4}{ }^{2-}$ from AMD (Equations (6)-(8)) [79-81]:

- The dissolution of $\mathrm{CaO}$ and $\mathrm{BaO}$ from CFA, which precipitates $\mathrm{SO}_{4}{ }^{2-}$ as $\mathrm{CaSO}_{4}$ or $\mathrm{BaSO}_{4}$;

- The precipitation of Fe hydroxide and oxyhydroxides, which results in adsorption of $\mathrm{SO}_{4}{ }^{2-}$ due to the large surface area;

- $\mathrm{Al}(\mathrm{OH})_{3}$ formation, which results in the reduction of $\mathrm{SO}_{4}{ }^{2-}$, and thus $\mathrm{SO}_{4}{ }^{2-}$ precipitate, as ettringite $\left(\mathrm{Ca}_{6} \mathrm{Al}_{2}\left(\mathrm{SO}_{4}\right)_{3}(\mathrm{OH})\right.$ at $\mathrm{pH}>9$.

The treatment of neutral mine water (NMW) with CFA has been found to result in low $\mathrm{SO}_{4}{ }^{2-}$ reduction; thus, the treated water does not meet an irrigation standard of $<500 \mathrm{ppm}$ sulphate. To improve $\mathrm{SO}_{4}{ }^{2-}$ reduction, seeding with $\mathrm{Al}(\mathrm{OH})_{3}$ and gypsum can increase the sulphate recovery from $60-90 \%$ [81]. Alkaline and acidic pre-treatment has also been 
applied to modify CFA prior to water treatment [82,83]. The treatment of wastewater with CFA is summarised in Table 4.

Table 4. The maximum adsorption capacities of various CFA materials.

\begin{tabular}{|c|c|c|c|c|c|}
\hline Source Material & $\begin{array}{c}\text { Optimum Mixing } \\
\text { Ratio }\end{array}$ & $\begin{array}{l}\text { Initial and Final } \mathrm{pH} \text {, } \\
\text { Reaction Time }\end{array}$ & $\begin{array}{c}\text { Adsorption } \\
\text { Capacity (mg/g) }\end{array}$ & Adsorption Efficiency & References \\
\hline Coal fly ash & - & $\mathrm{pH} 2-3,9-10,140 \mathrm{~min}$ & - & $\begin{array}{l}>90 \% \text { toxic metals, } \\
78 \% \text { sulphate }\end{array}$ & {$[78,79]$} \\
\hline $\begin{array}{l}\text { Fly ash, seeding } \\
\text { gypsum, } \mathrm{Al}(\mathrm{OH})_{3}\end{array}$ & $\begin{array}{c}1: 2,6.6 \pm 0.21,0.21 \\
12.25\end{array}$ & - & 213-1043 ppm & $\begin{array}{c}\text { Removal of } \\
79.57 \% \text { sulfate }\end{array}$ & [81] \\
\hline Modified fly ash & $\begin{array}{l}120 \mathrm{~g} / \mathrm{L}, 1.6 \\
2.8-6.6\end{array}$ & $180 \mathrm{~min}$ & - & $\begin{array}{c}89 \% \mathrm{Ni}, 92 \% \mathrm{Zn}, 94 \% \\
\mathrm{~Pb}, 96 \% \mathrm{Fe}, 60 \% \mathrm{Mn} \\
\text { and } 99 \mathrm{Al} \%\end{array}$ & [82] \\
\hline Modified fly ash &,- 4 & $36-120 \mathrm{~h}$ & - & $\begin{array}{l}82.4 \% \mathrm{Cd}^{2+}, 91.85 \% \\
\mathrm{Cu}^{2+} \text { and } 57.2 \% \mathrm{Zn}^{2}\end{array}$ & [83] \\
\hline
\end{tabular}

- Not available.

The treatment of wastewater with CFA also creates a secondary solid residue (SSR) (Figure 2). Quantitative analysis of the SSR has showed that gypsum is often the new mineral phase quantified after AMD treatment. These results have been confirmed by PHREEQC thermodynamic geochemical model, a predictive tool for the typical composition of precipitates [81]. The SSR can be re-used to synthesize the commercially viable geopolymers $[80,84]$ and zeolites $[85,86]$. The SSR can also be used as backfilling to prevent further generation of AMD. However, it has been observed that the addition of a pozzolanic binder (cement) is required in order to improve the strength of the backfill material [78,80]. Vadapalli et al., (2010) [87] synthesized Zeolite-P with $2 \mathrm{M} \mathrm{NaOH}$ solution at $100{ }^{\circ} \mathrm{C}$ using the SSR as a starting material. The synthesized zeolite had a high CEC value $(178.7 \mathrm{meq} / 100 \mathrm{~g})$ and a high surface area $\left(69.1 \mathrm{~m}^{2} / \mathrm{g}\right)$; thus, it could be used as a potential adsorbent for wastewater treatment [87].

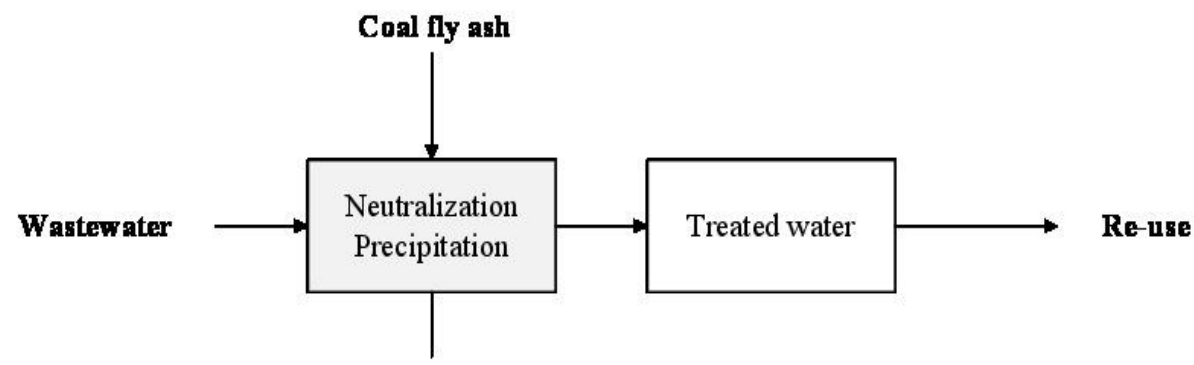

$\mathrm{CaSO}_{4} \cdot 2 \mathrm{H}_{2} \mathrm{O}$

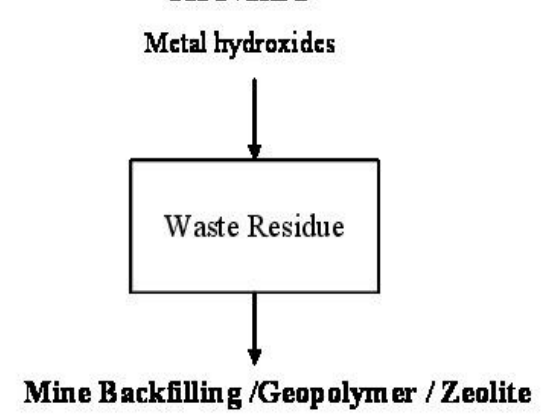

Figure 2. Schematic wastewater treatment with CFA.

In 2017, a patented study on AMD treatment with CFA, lime and $\mathrm{Al}(\mathrm{OH})_{3}$ was submitted to the Water Research Commission in South Africa (WRC Report No. 2129/1/18). A pilot plant of the process has also been designed and optimized with success in a jet 
loop reactor using neutral mine water with $\mathrm{pH} 8$ [88] and AMD with $\mathrm{pH} 2.2$ [69]. In the process, the major $\left(\mathrm{SO}_{4}{ }^{2-}, \mathrm{Al}, \mathrm{Fe}, \mathrm{Ca}, \mathrm{Mg}\right)$ and minor components are significantly lowered to $66.6 \%$ (equivalent to $728.56 \mathrm{~kg}$ ) in just one step. The purified water meets the water quality range for agriculture and irrigation in RSA. The characterization of the SSR has shown its suitability for backfilling of mine voids and geopolymer synthesis. The treatment of wastewater such as AMD with CFA could allow mining houses to comply with the environmental legislations on-site [48]. This treatment option is convenient for mining sites due to the low cost of transportation and can also achieve zero waste discharge.

\section{Adsorption of Organic Material}

Treatment of organic pollutants using CFA has been reviewed by Ahmaruzzaman (2010) [13] and Mushtaq et al., (2019) [89]. Photocatalysis and the Fenton reaction are attractive advanced oxidation processes (OAPs) in the scientific community that are considered "economic and cost effective" $[13,89,90]$. The application of Fe-based Fenton-like catalysis due to its wide $\mathrm{pH}$ application and the ability to be recycled and re-used is also attractive. In the Fenton process, the general reaction between $\mathrm{Fe}^{2+}$ and $\mathrm{H}_{2} \mathrm{O}_{2}$ produces hydroxyl radical $(\mathrm{OH})$, which is a strong oxidant for organic pollutants, by reducing the chemical oxygen demand (COD) value. CFA has been applied directly by Wang et al., (2018) [91] to treat coking wastewater. Their process has the potential to treat tertiary coking water, and the COD value was reduced to $89 \%$. CFA can also be treated prior the adsorption process. Wang et al., (2014) [92] treated CFA in $\mathrm{H}_{2} \mathrm{SO}_{4}$ prior to the adsorption process, and more than $99 \%$ of phenol was recovered. In a different study, CFA was treated under microwave irradiation, and the polymer-flooding wastewater was treated efficiently. The main advantage of the process was the capacity to recycle the catalyst with more than $90 \%$ catalytic performance [93].

\subsubsection{Adsorption of Gaseous Pollutants}

Alternatively to wastewater treatment, CFA has also been used for selective adsorption of major greenhouse gas emissions such as $\mathrm{CO}_{2}, \mathrm{SO}_{2}$ and $\mathrm{NO}_{\mathrm{x}}$ [94-96]. The most common application is the flue-gas desulfurization (FGD) of $\mathrm{SO}_{2}$ using a mixture of CFA and $\mathrm{Ca}(\mathrm{OH})_{2}$. Coal power plants emit large quantities of $\mathrm{SO}_{x}$. Thus, in an effort to reduce emission, power plants are forced to install flue-gas desulfurization (FGD). The adsorption capacity of $\mathrm{SO}_{2}$ is relatively enhanced with the addition of CFA compared to application using only $\mathrm{Ca}(\mathrm{OH})_{2}[97,98]$. However, due to a large consumption of $\mathrm{H}_{2} \mathrm{O}$ by this process, it was revised to utilise dry-type FGD. This method requires a large amount of adsorbent due to high calcium and sulphur molar ratio. The FGD material after adsorption has also been investigated as an effective building material by Telesca et al., (2013) [98] due to the formation of ettringite. Similar to calcium silicate hydrate (CSH) in Equations (1) and (2), ettringite is an important hydrating product of calcium aluminium sulphate $\left(4 \mathrm{CaOAl}_{2} \mathrm{O}_{3} 3 \mathrm{SO}_{3} 32 \mathrm{H}_{2} \mathrm{O}\right)$ cement, and it is known to form in a limited quantity during hydration of Portland cement from the reaction of gypsum, calcium aluminate and water [13,98]. Potential utilization of FGD products as building materials could be realised with the newly built Medupi and Kusile in South Africa with the FGD installation system.

\subsubsection{Synthesis of Zeolite}

Synthesis of zeolite materials from CFA has been studied and reviewed for industrial applications such as wastewater treatment and organic and inorganic pollutant treatment $[13,72,99]$. The zeolite type $X$ has the largest pore size $(7.3 \AA)$ and thus the highest cation exchange capacity (CEC) (Table 5). The conventional synthesis of zeolites involves alkaline activation by $\mathrm{NaOH}$ or $\mathrm{KOH}$ at high temperature $\left(50-150^{\circ} \mathrm{C}\right)$ for $2-14$ days. In the synthesis process, parameters which are essential include the $\mathrm{Si}: \mathrm{Al}$ ratio, $\mathrm{pH}$ control of the process and the synthesis time and temperature [13,72]. 
Table 5. Common zeolites synthesized and their relative properties (after $[72,100])$.

\begin{tabular}{cccc}
\hline Zeolite Class & Zeolite Type & Si/Al Ratio & Pore Size (̊̊) \\
\hline Low silica & Zeolite A, X & $1-1.5$ & 7.3 \\
Intermediate silica & Zeolite Y, P & $1.7-8$ & 4.1 \\
High silica & ZSM-5, EU-1 & $>10$ & 2.3 \\
Silica molecular sieves & Silicalite & $>100$ & $<1$ \\
\hline
\end{tabular}

Hydrothermal Synthesis

Murayama et al., (2002) [101] proposed that the synthesis of zeolite from CFA using an alkaline hydrothermal process occurs via dissolution of $\mathrm{Al}$ and $\mathrm{Si}$, condensation/gelation, nucleation and crystallization. The direct hydrothermal activation process is much simpler and less costly than the two-step hydrothermal technique [102,103]. Due to the crystalline mullite and quartz in CFA, it has been observed that the synthesized products have low conversion to zeolite phases and lack reproducibility. Thus, different synthesis methods have been altered and improved via hydrothermal activation [13,72]. Alternatively, sequential extraction of $\mathrm{Al}_{2} \mathrm{O}_{3}$ and $\mathrm{SiO}_{2}$ from CFA by acid and/or alkaline solution has also been investigated to synthesize zeolites of higher CEC [104]. However, treatment with concentrated acid destroys the zeolite structure and reduces the CEC value.

A pilot plant by Moreno et al., (2001) [12] was used to demonstrate treatment of AMD using CFA from Narcea and Teruel power plants. The zeolite synthesized was Na-P1 $\left(\mathrm{Na}_{6} \mathrm{Al}_{6} \mathrm{Si}_{10} \mathrm{O}_{32} \cdot 12 \mathrm{H}_{2} \mathrm{O}\right)$, with $2.7 \mathrm{CEC}$ value for Narcea CFA and 2.0 mequiv/g for Teruel CFA. Inada et al., (2005) [99] also synthesised Na-P1 $\left(\mathrm{Na}_{6} \mathrm{Al}_{6} \mathrm{Si}_{10} \mathrm{O}_{32} \cdot 12 \mathrm{H}_{2} \mathrm{O}\right)$ and hydroxysodalite $\left(\mathrm{Na}_{4} \mathrm{Al}_{3} \mathrm{Si}_{3} \mathrm{O}_{12}(\mathrm{OH})\right)$ using $\mathrm{NaOH}$ solution at $100{ }^{\circ} \mathrm{C}$. Zeolite Na-P1 achieved the highest CEC value (300 meq/100 g). The hydroxy-sodalite had the lowest CEC value and the smallest pore size of $2.3 \AA$.

Zeolite with the highest pore size (type $\mathrm{X}, \mathrm{Y}, \mathrm{P}$ ) is often desired due to diverse industrial applications. Querol et al., (2002) [72] found in a review that zeolite types $4 \mathrm{~A}$ and $\mathrm{X}$ can be synthesized by extracting $\mathrm{SiO}_{2}$ from CFA; however, the direct utilization of CFA results in zeolite with low CEC value due to temperature constrains [105]. Synthetic Na-X zeolite, using a patented process developed by Wdowin et al., (2014) [106], has been shown to remove xylene, benzene and toluene $[105,106]$. The sorption capacities of the tested materials followed the order xylenes $>$ toluene $>$ benzene, and $\mathrm{Na}-\mathrm{X}$ exhibited sorption performance in the range 383.67-582.91 $\mu \mathrm{g} / \mathrm{g}$ [105].

\section{Alternative Assisted Synthesis Methods}

Hydrothermal activation is known to affect the quality of the zeolite product and thus limits industrial applications. At high temperatures $\left(125-200{ }^{\circ} \mathrm{C}\right)$, zeolite A and zeolite $\mathrm{X}$ are difficult to form. A decrease in temperature requires long synthesis time, and thus it is time consuming $[13,72,99]$. Alternative synthesis methods such as alkaline-assisted fusion [107], have been investigated. Alkaline-assisted fusion is known for high yield of zeolite and lower environmental impact, since wastewater, which often requires further treatment, is not produced. However, the process is energy-intensive and expensive [13,72].

The conventional hydrothermal activation process uses a large amount of water. Therefore, due to the scarcity of fresh water, alternative water sources such as brine solution and mine waters have been investigated for zeolite synthesis $[108,109]$. Musyoka et al., (2011) [108] investigated the application of the industrial brine effluent located near the ash dump in Mpumalanga, South Africa. The synthesized hydroxyl sodalite zeolite was comparable to that obtained using freshwater under the same experimental conditions. In a different study, AMD and NMW were investigated as potential solvents [109]. The use of NMW formed Zeolite X and Na-P1. However, the application of AMD formed hydroxyl-sodalite with low CEC value. Nonetheless, both AMD and NMW are waste materials in mining sites. Therefore, their recycling produces benefits by adding value and also reducing the treatment costs. 


\section{Indirect Utilization of CFA}

CFA contains a number of valuable elements that can be recovered using metallurgical processes. According to Liu and $\mathrm{Li}$ (2015) [110], the extraction of these values from secondary material should be practical and economically feasible. Other than being practical and economically feasible, the process should also be sustainable. A sustainable process approach to earn revenue would require generation of more than one saleable product, minimization of waste disposal and regeneration of reagents [14]. Some indirect methods of utilizing CFA are discussed in the sections that follow.

\subsection{Recovery of the Magnetic Fraction}

In CFA, iron occurs as an oxide of magnetite $\left(\mathrm{Fe}_{3} \mathrm{O}_{4}\right)$, hematite $\left(\alpha-\mathrm{Fe}_{2} \mathrm{O}_{3}\right)$ and maghemite $\left(\gamma-\mathrm{Fe}_{2} \mathrm{O}_{3}\right)$. Based on their magnetic properties, magnetic particles in CFA can be separated from non-magnetic ones. The magnetic separation technique has been investigated as the cheapest alternative for Fe recovery from CFA. In this process, an external magnetic field is applied to separate or extract the highly magnetic fractions from the non-magnetic ones. Dry and wet magnetic separation are the most common techniques applied in high- and low-intensity magnetic separation conditions [111,112]. In CFA, the iron content varies from $2-20 \%$ due to the coal origin and the prevailing coal combustion conditions. For example, in South Africa, the iron content ranges from 2-6\%, while in China the maximum iron content can be up to $20 \%$ (Table 2).

Murtha and Burnet (1978) [111] first investigated the magnetic separation of CFA containing $18.5 \% \mathrm{Fe}_{2} \mathrm{O}_{3}$ using a low-gradient electromagnetic separator. For sufficient separation, the process was repeated three times, and $85 \% \mathrm{Fe}_{2} \mathrm{O}_{3}$ was extracted with less than $10 \%$ of $\mathrm{SiO}_{2}$ and $\mathrm{Al}_{2} \mathrm{O}_{3}$ co-extraction. The magnetic fraction was reported to be a dense material with very small particle sizes [111]. Shoumkova (2011) [113] conducted both wet and dry magnetic separation and reported that the separation efficiency is affected by the spinel magnetite where $\mathrm{Fe}$ is substituted with $\mathrm{Mg}, \mathrm{Ca}, \mathrm{Mn}$ or $\mathrm{Si}$. Thus, the magnetic fraction always contains low levels of impurities and has lower magnetic susceptibility compared to pure magnetite $\left(\mathrm{Fe}_{3} \mathrm{O}_{4}\right)$.

In 1980, Brown [114] patented a process that utilizes both wet and dry magnetic separation for the extraction of high-purity magnetic fractions. In this patent, CFA and water are introduced as slurry into a settling tank and then passed through two magnetic separators. The extracted magnetic fraction is further pulverized to $-342 \mu \mathrm{m}$ and then passed through the third magnetic separator to remove the remaining impurities. In 1984, a similar process was also patented by Aldrich (1984) [112]. In this process, the first step is dry magnetic separation. The extracted magnetic fraction is then ground to $-325 \mu \mathrm{m}$, followed by wet magnetic separation to improve the quality of the extracted fraction. This process recovered up to $98 \%$ magnetite with a specific gravity of 4.5 [112].

Dense medium separators are the most widely applied gravity concentration units in coal cleaning. Magnetite is the common material used to form the suspension. The magnetic fraction in CFA has been identified as an alternative source for magnetite [106,110-112]. Therefore, the substitution of fresh magnetite with CFA magnetic fraction is a potential market for using CFA to clean the on-site coal, thereby reducing the operating costs associated with buying fresh magnetite $[107,113]$. The CFA magnetic fraction also seems to be a potential source of iron ore. However, Murtha and Burnet (1978) reported that further processing should be conducted to reduce the amount of $\mathrm{SiO}_{2}$ and $\mathrm{Al}_{2} \mathrm{O}_{3}$. Acceptable material for blast furnace feed should have combined silica and the alumina content of less than 5\% [106]. Shoumkova (2011) [113] and Strzałkowska (2021) [115] also observed that the magnetic fraction (magnetite and hematite) is co-extracted with quartz $\left(\mathrm{SiO}_{2}\right)$, mullite $\left(3 \mathrm{Al}_{2} \mathrm{O}_{3} \cdot 2 \mathrm{SiO}_{2}\right)$ and the amorphous phase due to the co-existence of these phases with the Fe-containing mineral [115]. Nonetheless, magnetic separation can be carried out using different methods depending on the required final product quality and its intended use [113]. The ferrospheric magnetic particles are characterised as dendritic-skeletal, granular and hollow in structure, and their particle size can range from 1 to $200 \mu \mathrm{m}[113,115]$. Strzałkowska 
(2021) [115] proposed that the magnetic fraction can further be investigated as a potential catalyst in wastewater treatment. In the extraction of rare earth elements, magnetic separation is also used to concentrate the REEs [116]. The non-magnetic fraction, which is enriched with aluminium and silica, can further be utilized in the building and construction industry [117], used for zeolite synthesis [116], or processed for the metallurgical recovery of alumina and REEs [116,118,119].

\subsection{Recovery of Alumina, Titanium and Iron}

Aluminium has wide industrial application in the construction, electrical, mechanical and transportation industry. It has been found to be attractive due to its remarkable properties such as "high thermal and electrical conductivity, corrosion resistance and high strength-to-weight ratio" [30]. CFA contains 20-30\% $\mathrm{Al}_{2} \mathrm{O}_{3}$, which is among the highest known alumina contents, second only to bauxite, whose alumina content is in the range $30-60 \%$ (Table 6). Bauxite is the primary source of alumina in the world and is commercially processed using the conventional and economically proven Bayer process. In the Bayer process, the bauxite ore is leached in a hot caustic soda solution at high pressure and temperature to form sodium aluminate solution. The hydroxide solution (Equation (9)) is then cooled to precipitate (seed precipitation) the aluminium hydroxide. The alumina crystals are then calcined at $>1000{ }^{\circ} \mathrm{C}$ to form the final alumina product (Equation (10)), which is further refined to produce the aluminium metal using the Hall-Heroult electrolytic process $[30,120]$.

$$
\begin{gathered}
\mathrm{Al}_{2} \mathrm{O}_{3}+2 \mathrm{OH}^{-}+3 \mathrm{H}_{2} \mathrm{O} \rightarrow 2 \mathrm{Al}(\mathrm{OH})_{3} \\
2 \mathrm{Al}(\mathrm{OH})_{3} \rightarrow \mathrm{Al}_{2} \mathrm{O}_{3}+3 \mathrm{H}_{2} \mathrm{O}
\end{gathered}
$$

The Bayer process is selective in Fe and Ti separation due to their low solubility in alkaline solution [121]. However, the process is only feasible for bauxite containing a high mass ratio of alumina to silica (A:S) above 9 [30,122]. In CFA, the silica concentration is greater than $40 \%$ with A:S ratio of $1-2$. Both silica and alumina react to form the insoluble and difficult-to-treat sodium aluminium hydro-silicate $[110,123]$. Therefore, for the extraction of alumina from CFA, several methods have been investigated. Although no commercial process is available, advances have been made in direct acid leaching, sinter processes and the chlorination process.

Table 6. Typical chemical composition of CFA, bauxite and smelter-grade alumina (after [14,124]).

\begin{tabular}{cccc}
\hline Component & Coal Fly Ash (CFA) & Bauxite & Smelter-Grade \\
\hline $\mathrm{SiO}_{2}$ & $40-60$ & $<10$ & $0.005-0.025$ \\
$\mathrm{Al}_{2} \mathrm{O}_{3}$ & $20-31$ & $30-60$ & $>99.3$ \\
$\mathrm{CaO}$ & $3-11$ & $0.1-2.0$ & $0.005-0.020$ \\
$\mathrm{Fe}_{2} \mathrm{O}_{3}$ & $2-6$ & $1-30$ & $0.001-0.008$ \\
$\mathrm{TiO}_{2}$ & $1.3-1.7$ & $<10$ & $<0.020$ \\
$\mathrm{P}_{2} \mathrm{O}_{5}$ & $<1.0$ & $<1.1$ & $<0.0015$ \\
\hline
\end{tabular}

\subsubsection{Direct Acid Leaching}

The direct acid leaching of CFA has resulted in low alumina extraction at low acid concentration and ambient temperature due to the dissimilar alumina phases. Shemi et al., (2015) [20] observed that alumina in the amorphous phase is recoverable up to $89.3 \%$ in $6 \mathrm{M}$ $\mathrm{H}_{2} \mathrm{SO}_{4}$, while the alumina associated with the mullite $\left(3 \mathrm{Al}_{2} \mathrm{O}_{3} \cdot 2 \mathrm{SiO}_{2}\right)$ remained unreactive. However, several workers have reported that at high pressure, high temperature and high acid concentrations, higher alumina extraction efficiency is possible [125-127].

In a study by Nayak and Panda (2010) [125], CFA was leached in $18 \mathrm{M} \mathrm{H}_{2} \mathrm{SO}_{4}$ at $200{ }^{\circ} \mathrm{C}$, and more than $82 \% \mathrm{Al}_{2} \mathrm{O}_{3}$ was recovered. However, under these conditions, they observed a formation of acid fumes due to acid boiling. A recent study by Wei et al., (2018) [127] also reported that alumina can be recovered significantly at high temperatures and high acid concentrations. In this study [127], CFA was mixed with concentrated sulphuric acid 
$\left(\mathrm{H}_{2} \mathrm{SO}_{4}\right.$ : CFA, 1.2) at $220-320{ }^{\circ} \mathrm{C}$ to form milosevichite clinker in Equation (11), which is soluble in boiling water. The alumina recovery reached up to $86 \%$ after $120 \mathrm{~min}$ of leaching. The leached solution was then evaporated at $115-117^{\circ} \mathrm{C}$, and $\mathrm{Al}_{2}\left(\mathrm{SO}_{4}\right)_{3} \cdot 18 \mathrm{H}_{2} \mathrm{O}$ was directly crystallized. The crystalloids were dehydrated at $370{ }^{\circ} \mathrm{C}$ and further calcined at $870{ }^{\circ} \mathrm{C}$ to form the final alumina product $\left(\gamma-\mathrm{Al}_{2} \mathrm{O}_{3}\right)$. Reclamation and recycling of $\mathrm{SO}_{3}$ in this process was achieved by using a reflux condenser device, which was installed on the flask [127]. In this process, direct alumina crystallization was reported possible, thus reducing the cost of downstream purification techniques required to generate smelter-grade alumina.

$$
3 \mathrm{Al}_{2} \mathrm{O}_{3} \cdot 2 \mathrm{SiO}_{2(\mathrm{~S})}+\mathrm{H}_{2} \mathrm{SO}_{4(1)} \rightarrow \mathrm{Al}_{2}\left(\mathrm{SO}_{4}\right)_{3(\mathrm{~s})}+2 \mathrm{SiO}_{2(\mathrm{~s})}
$$

Orbite Alumnae in Canada has patented a chloride process for the extraction of alumina from bauxite residue and CFA secondary resources (Figure 3). The process uses $\mathrm{HCl}$ to leach CFA at high-temperature and -pressure conditions. In this process, high coextraction of $\mathrm{Al}$ and Fe occurs, while Ti remains in the residue. Alumina chloride is directly crystallized from the resulting leach solution to produce smelter-grade alumina. However, to aid crystallization, highly toxic chlorine gas is required. The remaining raffinate is hydrolyzed and calcined to produce $\mathrm{Fe}_{2} \mathrm{O}_{3}$. The recovery of $\mathrm{Ti}$ in the residue is patented for production of high purity $\mathrm{TiO}_{2}[128,129]$. The main advantage of the process is the extraction of more than one saleable product. However, the boiling point (b.p) of $\mathrm{HCl}$ decreases with an increase in molarity (at $2.9 \mathrm{M}$, the b.p of $\mathrm{HCl}$ is $103{ }^{\circ} \mathrm{C}$, whilst at $12.4 \mathrm{M}$ it is $48^{\circ} \mathrm{C}$ ); therefore, it forms a corrosive mist, which leads to high equipment costs $[30,130]$.

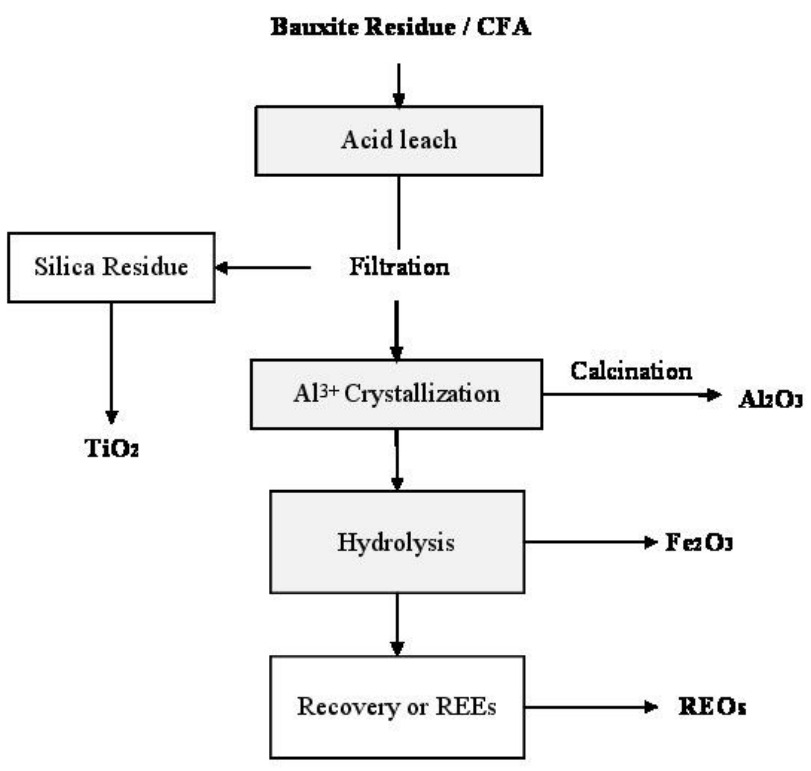

Figure 3. Schematic representation of the chloride process (after [128,129]).

\subsubsection{Sinter Process}

Due to the two dissimilar alumina phases in CFA, thermal pre-treatment methods that involve sintering were introduced by several workers to transform the mullite into a soluble phase [131-134]. The pre-treatment involves high-temperature chemical transformation (usually in excess of $1000{ }^{\circ} \mathrm{C}$ ) of the refractory mullite into a more soluble compound of anorthite or gehlenite (Equations (12) and (13)). After sintering, the sintered CFA is dissolvable in alkaline or acidic solutions, hence the classification of sinter-based processes as indirect acid leaching and indirect alkaline leaching $[14,121]$.

$$
\begin{gathered}
3 \mathrm{Al}_{2} \mathrm{O}_{3} \cdot 2 \mathrm{SiO}_{2}+3 \mathrm{CaO}+4 \mathrm{SiO}_{2} \rightarrow 3\left(\mathrm{CaO} \cdot \mathrm{Al}_{2} \mathrm{O}_{2} \cdot 2 \mathrm{SiO}_{2}\right) \\
3 \mathrm{Al}_{2} \mathrm{O}_{3} \cdot 2 \mathrm{SiO}_{2}+5 \mathrm{CaO}+4 \mathrm{SiO}_{2} \rightarrow 3\left(2 \mathrm{CaO} \cdot \mathrm{Al}_{2} \mathrm{O}_{2} \cdot 2 \mathrm{SiO}_{2}\right)
\end{gathered}
$$




\section{Indirect Acid Leaching}

In this process, the sintered CFA material is leached in an acidic solution to recover alumina. Several workers have investigated the sinter-acid leaching method and successfully obtained high alumina recovery for commercial exploitation [132-135]. However, the cost implications involved in hydrothermal pre-treatment are a major concern. Additionally, further purification is required to produce smelter-grade alumina, which adds to the processing costs.

Matjie et al., (2005) [134] first investigated the possible saleable products that can be co-recovered with alumina. In the lime-sinter process by Matjie et al., (2005) [134] as shown in Figure 4, CFA was pelletized in a mixture containing a CFA: Coal: $\mathrm{CaO}$ ratio of 5:4:1, followed by sintering at $1000-1100{ }^{\circ} \mathrm{C}$ for a maximum of $180 \mathrm{~min}$. The sintered pellets were then leached for $4 \mathrm{~h}$ with $6.12 \mathrm{M} \mathrm{H}_{2} \mathrm{SO}_{4}$ at $80{ }^{\circ} \mathrm{C}$. The $\mathrm{pH}$ of the leach solution was adjusted using $\mathrm{NaOH}$ and both $\mathrm{Ti}^{4+}$ and $\mathrm{Fe}^{2+}$ were selectively extracted into the organic solution using Primine JMT. Selective hydroxide precipitation was then conducted to recover $\mathrm{Ti}(\mathrm{OH})_{2}$ and $\mathrm{Fe}(\mathrm{OH})_{3}$ from the strip liquor. The remaining raffinate was then crystallized and calcined to produce high purity alumina. This process has the potential to be commercialized, as alumina, titanium and iron are extracted with high purity. However, the cost implication of commercializing such a process is the main drawback. The process reagents such as amines and sodium hydroxides are also expensive and thus should be recycled during processing or substituted with the lower cost reagents. Matjie et al., (2005) [134] also suggested that the remaining silica residue has the potential of being used as a lightweight aggregate in the construction industry.

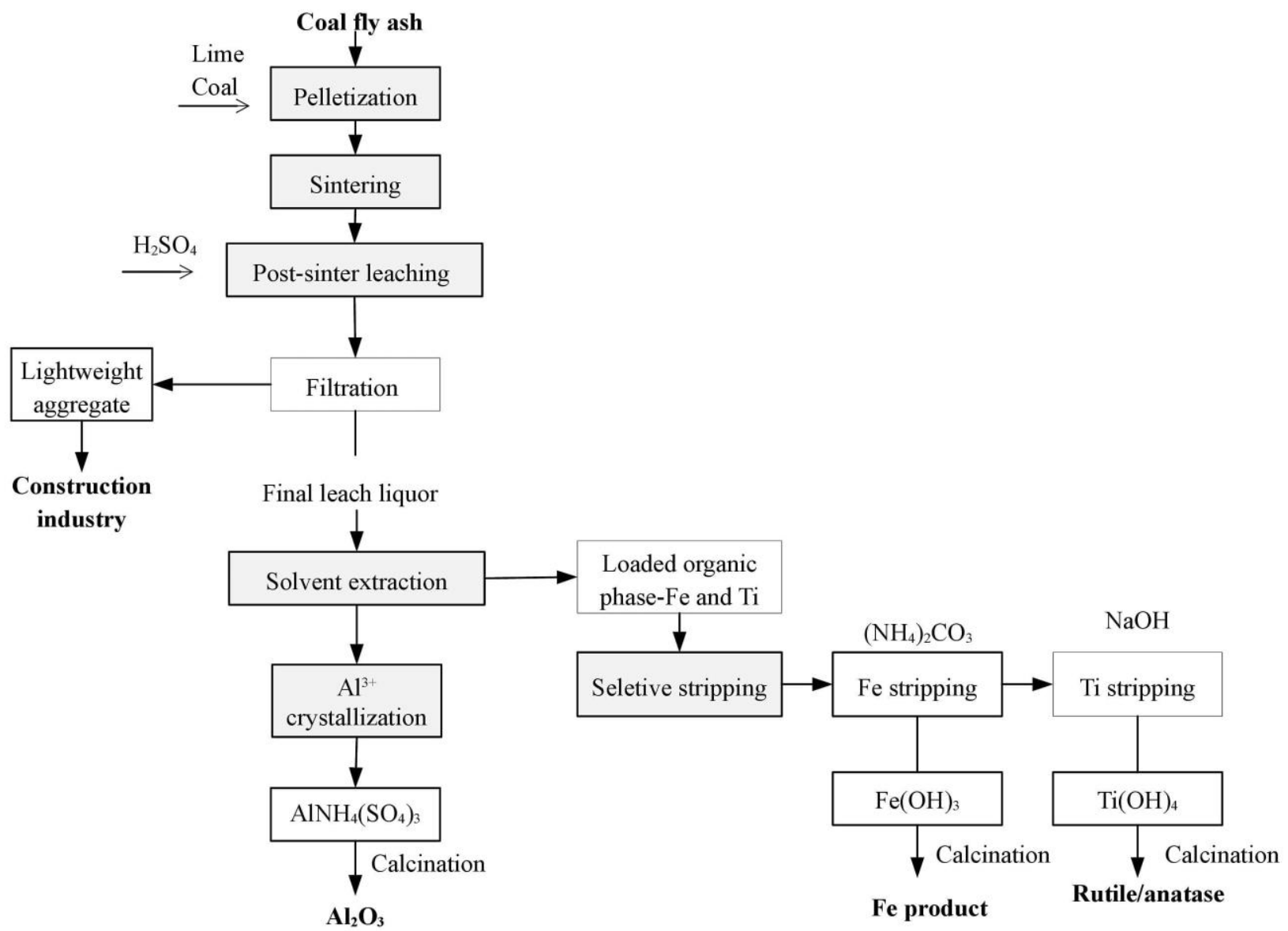

Figure 4. The lime-sinter-acid leach process and purification for alumina production [134]. 
Indirect Alkaline Leaching

The sintered CFA material can also be leached in an alkaline solution, which is also known as the indirect alkaline leaching $\left(\mathrm{CaO}, \mathrm{Na}_{2} \mathrm{CO}_{3}, \mathrm{NaOH}\right.$ or $\left.\mathrm{H}_{2} \mathrm{O}\right)[15,131,136-138]$. In the lime-sinter process, CFA reacts with lime at $>1100{ }^{\circ} \mathrm{C}$ to form soluble calcium aluminate and the insoluble di-calcium silicate. The sintered CFA disintegrates at $<500{ }^{\circ} \mathrm{C}$ into a fine powder and therefore can be leached in $\mathrm{Na}_{2} \mathrm{CO}_{3}$. In this process (Figure 5), the remaining residue can be utilized as feed for cement production [15].

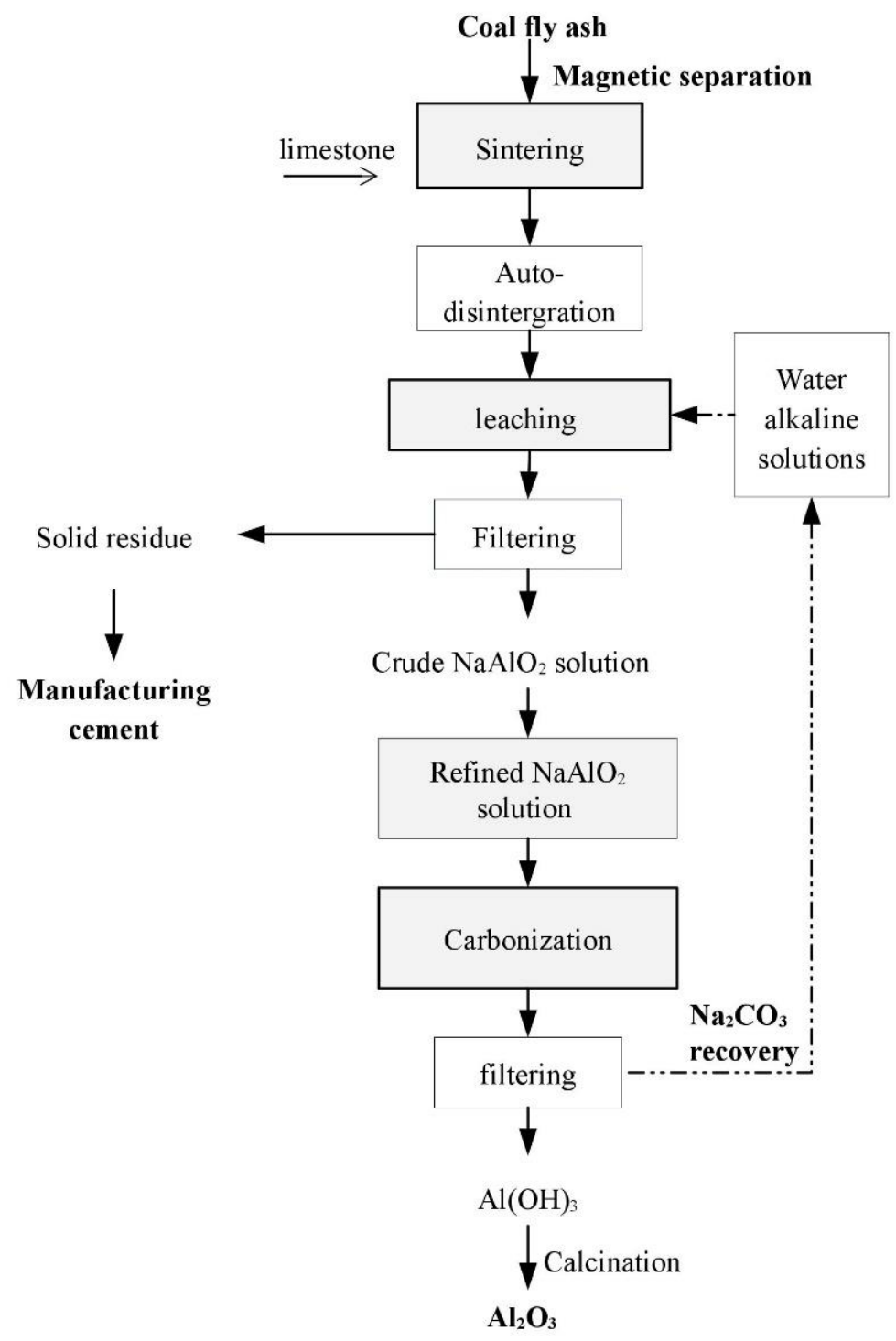

Figure 5. The lime-sinter alkaline process [15].

The disadvantages of the lime-sinter alkaline process are its large consumption of the alkaline solution and high sintering temperature, which makes the process very energyintensive [14,15]. Based on the lime-sinter process, the Melic Sea Group completed an alumina project worth 200,000 tonnes per year in China. The project was unsuccessful and ceased production $[53,137]$. Pre-desilication was introduced to reduce the high lime consumption, and the combined process of pre-desilication and lime-sintering was adopted [15,53]. In this process, CFA is first "desilicated" [15] to remove $>40 \mathrm{wt} \% \mathrm{SiO}_{2}$ by alkaline leaching, thus increasing the $\mathrm{Al}_{2} \mathrm{O}_{3} / \mathrm{SiO}_{2}$ mass ratio (0.8-1.0). The desilicated CFA is then sintered and leached in an alkaline solution to recover more than $90 \% \mathrm{Al}_{2} \mathrm{O}_{3}[139,140]$.

Although a lot of effort has been made to commercialize CFA in China, the production ceased due to the high-energy consumption of hydrothermal pre-treatment and the excess 
silica-rich residue (dicalcium silicate), which has limited utilization, as well as the complex operation of the plants, which resulted in no profit $[15,53]$. A high-alumina coal fly ash (HAFA) with $40-50 \% \mathrm{Al}_{2} \mathrm{O}_{3}$ in northwestern China attracted attention to commercialize CFA processing, but it was realized that for more economic benefits, it would be prudent to extract more valuable materials such as gallium and germanium in addition to alumina. However, such a multi-product process has not yet been commercialized, and the extraction of alumina from CFA has had to be revised [15,53,137].

\section{Acid Leach-Sinter-Acid Leach}

The distributions of alumina in two dissimilar phases has also lead to the development of a novel two-step leaching process (Figure 6) [20]. Shemi et al., (2015) [20] found that when the alumina-bearing amorphous and mullite phases are leached separately, they yield high extraction efficiency. In the first pre-sinter stage, alumina in the amorphous phase is leached with $6 \mathrm{M} \mathrm{H}_{2} \mathrm{SO}_{4}$ solution for $10 \mathrm{~h}$ at $82{ }^{\circ} \mathrm{C}$ to extract $24.8 \% \mathrm{Al}_{2} \mathrm{O}_{3}$, which corresponds to $89.3 \%$ aluminium recovery from the amorphous phase. The remaining residue is mixed with coal and lime, pelletized, sintered at $\sim 1100{ }^{\circ} \mathrm{C}$ and then leached with $2 \mathrm{M} \mathrm{H}_{2} \mathrm{SO}_{4}$ at $82{ }^{\circ} \mathrm{C}$. This post-sinter stage extracts $84.3 \%$ aluminium from the mullite phase. The overall process extracted a maximum of $88.2 \% \mathrm{Al}_{2} \mathrm{O}_{3}$ from the amorphous and mullite phase.

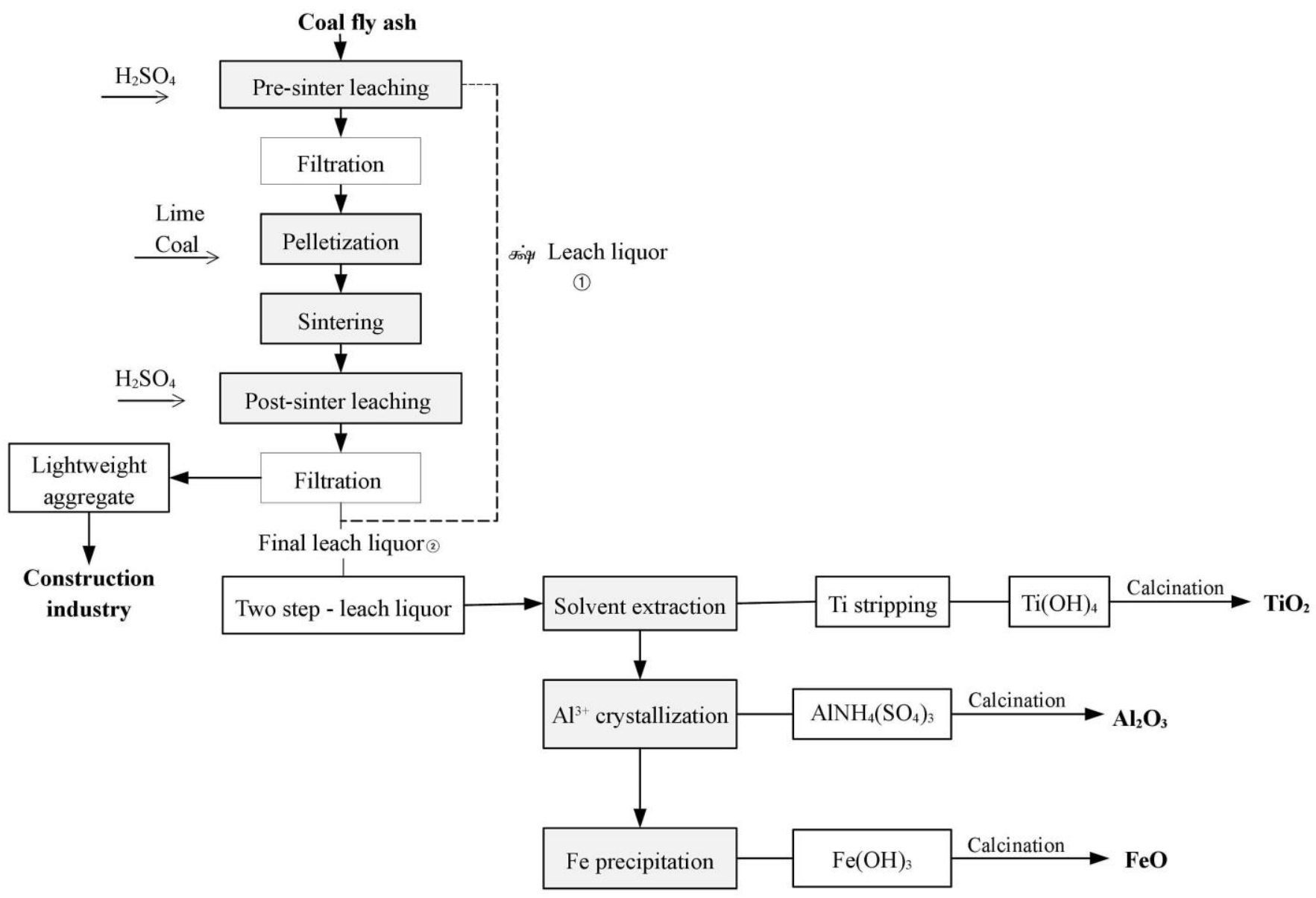

Figure 6. A two-step leaching process [20] and the purification by solvent extraction and precipitation (after [141]).

The two-step leaching process also resulted in high titanium and iron co-extraction. Rampou and collaborators (2017) [141] developed an integrated precipitation and solvent extraction method to purify the subsequent leach liquor generated by the leach-sinterleach process. Iron fillings were added to the solution to reduce $\mathrm{Fe}^{3+}$ to $\mathrm{Fe}^{2+}$. Solvent 
extraction was then performed to selectively extract $\mathrm{Ti}^{4+}$ with primine JMT $(10 \%) /$ kerosene (A/O: 1:1, $15 \mathrm{~min}$ ), followed by stripping with $\mathrm{NH}_{4} \mathrm{OH}$. The $\mathrm{Ti}(\mathrm{OH})_{4}$ was then calcined to produce $93.3 \% \mathrm{TiO}_{2}$. The titanium oxide product was predominantly rutile, which is a precursor for paint pigmentation, based on the American Society for Testing and Materials (ASTM) standard. The calcined $\mathrm{TiO}_{2}$ resembled type II titanium pigment in composition. Aluminium was then crystallised as $\mathrm{AlNH}_{4}(\mathrm{SO})_{3}$ from the raffinate solution and subsequently calcined to produce smelter-grade alumina containing $96 \% \mathrm{Al}_{2} \mathrm{O}_{3}$. The remaining solution was further processed to precipitate out iron as $\mathrm{Fe}(\mathrm{OH})_{2}$. The calcined iron oxide predominantly contained hematite $\left(\mathrm{Fe}_{2} \mathrm{O}_{3}, 79.29 \%\right)$ with an equivalent Fe content of $55.5 \%$ [141].

Hematite is the common iron content in most mining site [142]. The average grade in iron processing can be $>60 \mathrm{wt} \%$ Fe. Therefore, for mining operation to be commercially feasible, iron deposits with 56-59 wt\% Fe grade are accepted [143]. The iron precipitate was therefore recommended as acceptable raw material for commercial steel making operations [141]. In agreement with Matjie et al., (2005) [134], Shemi et al., (2015) [20] also recommended that the remaining silica residue can be used as lightweight aggregate material.

\subsubsection{HiChlor Process}

The HiChlor process is a high-temperature chlorination process that was initially developed to compete with the Hall-Heroult electrolysis process for the production of aluminium. In the Hall-Heroult process, alumina from the Bayer process is dissolved in molten cryolite $\left(\mathrm{Na}_{3} \mathrm{AlF}_{6}\right)$ and electrolyzed using carbon electrodes to produce pure $\mathrm{Al}$ metal (Equation (14)). In the HiChlor process, the purified $\mathrm{Al}_{2} \mathrm{O}_{3}$ is chlorinated to $\mathrm{AlCl}_{3}$, dissolved in a molten salt and thus electrolyzed using graphite electrodes (Equation (15)). The HiChlor process showed potential in the production of alumina directly from bauxite, and the possibility of using the process on CFA was also postulated by Øye (2018) [144]. For CFA, the major challenge of the HiChlor process was the formation of difficult-to-separate $\mathrm{FeAlCl}_{6(\mathrm{~g})}$ between $200-700{ }^{\circ} \mathrm{C}$. Despite introducing magnetic separation as a pre-treatment method to remove iron, only one-third of the Fe was recovered.

$$
\begin{gathered}
2 \mathrm{Al}_{2} \mathrm{O}_{3}+3 \mathrm{C} \rightarrow 4 \mathrm{Al}+3 \mathrm{CO}_{2} \\
3 \mathrm{Al}_{2} \mathrm{O}_{3}+3 \mathrm{C}+6 \mathrm{Cl}_{2} \rightarrow 4 \mathrm{AlCl}_{3}+3 \mathrm{CO}_{2}
\end{gathered}
$$

Another setback for the HiChlor process was that it is not environmentally friendly, and therefore it was never commercialised $[145,146]$. To date, the largest research effort has been made by Alcoa with a demonstrative plant in 1976 that produced more than 13 tonnes of aluminium per day. However, the company ceased production in 1985. Alcoa and Rio Tinto joined venture as ELYSIS to commercialise the inert $\mathrm{O}_{2}$ anode process. SINTEF, Norway, is also reviewing the HiChlor process, with active research underway. The high interest in the chlorination process is mainly due to its low energy consumption and its high carbon reduction footprint $[147,148]$.

\subsection{Recovery of Rare Earth Elements}

The REEs are defined as "strategic and critical elements" [147]. Their global demand is increasing with increasing demand for their application in green energy technologies such as solar panels, wind-powered turbines and low-energy light bulbs. Their distinct properties such as high magnetism (but light weight) and good electrical conductivity have played a major role in the development of technological devices. It has thus been noted that the future of renewables heavily depends on REEs [28,147]. Minable concentrates of the REEs exist in South Africa, Australia, the United States, China and India. However, only a few countries have the potential to beneficiate the REEs to the refining stage. For example, outside China, only Lynas Mount Weld (Australia) (LREEs) and Molycorp Mountain Pass (USA) have the capacity to separate and refine the REEs [28,149]. According to the 2020 US Geological Survey $[73,74]$, China produces almost $95 \%$ and consumes $75 \%$ of the global 
production of rare earth metals. Therefore, alternative sustainable deposits outside China are being heavily investigated for a sustainable future supply.

The extraction of REEs from secondary material has been considered as an additional source to meet the increasing demand. Waste materials such as bauxite residue and CFA have received attention, as they contain considerable quantities of REEs (100-1000 ppm) $[27,28,149]$. The exploitation of these secondary materials has an inherent advantage of reducing environmental impacts. The extraction of REEs from CFA is currently under on-going research. The United States Department of Energy has considerable research focused on the extraction of REEs from coal and coal by-products [150].

\subsubsection{Alkali-Acid Leaching of the REEs}

The extraction of REEs from CFA has been studied using commercially available lixiviants such as $\mathrm{HCl}, \mathrm{HNO}_{3}$ and $\mathrm{H}_{2} \mathrm{SO}_{4}$. Direct acid leaching has resulted in high REEs recoveries, but in other studies, low or no REEs recoveries have been reported [37,151,152]. King et al., (2018) [153] studied the recovery of REEs from different CFA materials in the USA. The CFA material from Powder River Basin (PRB) showed nearly 100\% REEs recovery with $6 \mathrm{M} \mathrm{HCl}$ at $85^{\circ} \mathrm{C}$ for $4 \mathrm{~h}$. However, under the same experimental conditions, the Appalachian-based coal ashes (APCA) showed 57\% recovery, and for the Illinois Basin, $43 \%$ REEs recovery was attained. From these results, it was concluded that the extraction efficiency varied due to the different compositions and distributions of the REEs in the CFA [153]. In a different study, Sedres (2016) [37] observed no REE extraction from the CFA obtained from Matla power plant, South Africa, despite using both $\mathrm{HCl}\left(0-10 \mathrm{M}, 100^{\circ} \mathrm{C}\right)$ and $\mathrm{H}_{2} \mathrm{SO}_{4}\left(5-18.2 \mathrm{M}, 85-100{ }^{\circ} \mathrm{C}\right)$. Although the direct acid leaching was not effective on some CFA material, it has been observed that the leaching efficiency follows the order $\mathrm{HCl}>\mathrm{HNO}_{3}>\mathrm{H}_{2} \mathrm{SO}_{4}$. Thus, $\mathrm{HCl}$ is often the best lixiviant for extracting REEs $[151,153,154]$.

Cao et al., (2018) [152] studied the factors which affect REEs recovery in CFA using $\mathrm{HCl}$. In this study, CFA was leached for $120 \mathrm{~min}$ at $200 \mathrm{rpm}, 60^{\circ} \mathrm{C}, 3 \mathrm{M} \mathrm{HCl}$ using a liquidsolid ratio of $10(\mathrm{v} / \mathrm{m})$. A maximum of $71.9 \% \mathrm{La}, 66.0 \%$ Ce and $61.9 \% \mathrm{Nd}$ were recovered. Incidentally, the high-pressure chloride process by the Orbite Alumnae in Canada has also been reported to fully recover REEs [128,129].

The pre-treatment of CFA prior to acid leaching has been effective for high recovery of REEs. In this process, CFA is roasted or calcined at temperatures below the melting point of the salt used, thus liberating the REEs enclosed in the aluminosilicate [153,155-157]. In a study by Tang et al., (2019) [156], CFA was roasted at $860{ }^{\circ} \mathrm{C}$ (CFA: $\left.\mathrm{Na}_{2} \mathrm{CO}_{3}, 1: 1\right)$ and leached with $3 \mathrm{M} \mathrm{HCl}$ for $2 \mathrm{~h}$. The maximum REEs leaching efficiency was reported as $72.78 \%$.

\subsubsection{Bioleaching of REEs}

Bioleaching is a commercially viable process for the recovery of gold, nickel, and uranium from low-grade ores and mineral concentrates [158]. In CFA, it was first investigated for alumina recovery as a cost-effective alternative to the inorganic chemical extraction process. In this process, the bacterial microbe is used as a catalyst that facilitates the leaching process, either directly or indirectly. The process is often ideal for low-grade sulphides, as the microorganisms uses the metal sulphates, which have low solubility, as the source of energy to form $\mathrm{H}_{2} \mathrm{SO}_{4}$, which is the main cell metabolite in the leaching process $[158,159]$. In the extraction of REEs, the acid and ferric ions are useful in the leaching process (Equations (17)-(19)) [160,161]. It is also noted from literature [162,163] that most bacterial microbes often thrive at low $\mathrm{pH}$; thus, alkaline materials such as CFA show slow bacteria growth, resulting in low leaching efficiency. However, the addition of elemental sulphur can improve the leaching efficiency by supplying an additional energy source $[162,163]$.

$$
\begin{gathered}
\mathrm{FeS}_{2}+2 \mathrm{Fe}^{3+} \rightarrow 3 \mathrm{Fe}^{2+}+2 \mathrm{~S}^{\mathrm{o}} \\
2 \mathrm{~S}^{\mathrm{o}}+3 \mathrm{O}_{2}+2 \mathrm{H}_{2} \mathrm{O} \rightarrow 2 \mathrm{SO}_{4}^{2-}+4 \mathrm{H}^{+} \\
4 \mathrm{Fe}^{2+}+\mathrm{O}_{2}+4 \mathrm{H}^{+} \rightarrow 4 \mathrm{Fe}^{3+}+2 \mathrm{H}_{2} \mathrm{O}
\end{gathered}
$$




$$
(\mathrm{REE}) \mathrm{FeS}_{2(\mathrm{~s})}+3 \mathrm{Fe}^{3+} \rightarrow 4 \mathrm{Fe}^{2+}+\mathrm{REE}_{(\mathrm{aq})}^{+}+2 \mathrm{~S}^{\mathrm{o}}
$$

A batch experiment was first performed for the extraction of alumina and iron by suspending up to $10 \%(w / v)$ CFA in Thiobacillu thiooxidans inoculum, containing a growth medium for 21 days [163]. $\mathrm{Up}$ to $25 \% \mathrm{Al}_{2} \mathrm{O}_{3}$ and $22 \% \mathrm{Fe}_{2} \mathrm{O}_{3}$ were recovered. The precipitation of calcium sulphate interfered with cell attachment to sulphur particles, and this delayed the cell growth rates. The pre-treatment of CFA with $\mathrm{HCl}$ to remove $\mathrm{CaO}$ had no significant impact, and thus, the overall process was found to be ineffective, with low alumina selectivity and slow leaching kinetics [163]. In a recent study, Fan et al., (2019) [164] activated CFA by roasting with $\mathrm{Na}_{2} \mathrm{CO}_{3}$ at $850{ }^{\circ} \mathrm{C}$ for $2 \mathrm{~h}$ prior to leaching. The CFA and pyrite (source of sulphur) were mixed, and the $\mathrm{pH}$ was adjusted to $1.5-2.5$ using $\mathrm{H}_{2} \mathrm{SO}_{4}$. The meso-acidophilic Acidithiobacillus ferrooxidans were used as a source of pyrite oxidation and to therefore produce $\mathrm{H}_{2} \mathrm{SO}_{4}$ and $\mathrm{Fe}^{3+}$ (Equations (16)-(18)). After 12 days and 8 days of incubation, $91.2 \% \mathrm{Al}$ and $63.4 \% \mathrm{Ce}$ were recovered.

\subsubsection{Purification and Concentration of REEs}

To upgrade and concentrate REEs, it is important to use an appropriate selective purification technique. Most leaching processes (i.e., acid leaching, bioleaching) are not selective and thus result in the co-extraction of $\mathrm{Al}, \mathrm{Ti}, \mathrm{Fe}$ and $\mathrm{Ca}$ with REEs. As such, there is need for inexpensive and environmentally friendly purification steps which have a high selectivity for REEs. Common purification techniques that have been investigated are discussed:

\section{- $\quad$ Adsorption of REEs}

A number of adsorbents, such as zeolite and silica, have been studied and reviewed for their adsorption capacity for REEs [165]. However, research on the adsorption of REEs from a complex matrix such as CFA is limited. In biosorption, a microbial cell surface is used to adsorb metals from dilute solutions. The microorganism acts as biosorbant or bio-accumulator for metals. The adsorption process is contributed by the cell surface functional groups such as carboxyl $\left(\mathrm{COO}^{-}\right)$, Hydroxyl $\left(\mathrm{OH}^{-}\right)$and sulphhydryl $\left(\mathrm{HS}^{-}\right)$, which enables the adsorption of metals to the microbial surface. The adsorbed REEs can easily be recovered by desorption with water-soluble organic acids, and the biomass can be recycled [166,167]. A study by Ponou et al., (2016) [166] has so far revealed that REEs can be selectively adsorbed on a carbonized ginkgo leaf after leaching with $\mathrm{HCl}$. The biosorption processes is carried out at $\mathrm{pH} 3$ for $\mathrm{Er}$ and $\mathrm{pH} 5$ for La and Ce.

- Application of Ionic Liquids in REEs Extraction

Ionic liquids (ILs) are known as potential green solvents with high selectivity. Similar to the biosorption process, limited research is available on these lixiviants. However, coal ash from Jiangxi, Guizhou, power plant in China was investigated for selective separation of REEs using ILs. To the chloride-leached solution containing REEs, methyltrioctylammonium chloride $\left(\left(\mathrm{N}_{1888}\right) \mathrm{Cl}\right)$ was first used to selectively separate $\mathrm{Fe}^{3+}$. The remaining raffinate was further processed to purify the REEs by selectively extracting them using Methyltrioctylammonium-sec-octylphenoxyacetate $\left(\mathrm{N}_{1888}\right.$-SOPAA). The co-extraction of calcium was observed, and it was selectively removed with $\mathrm{NH}_{4} \mathrm{HCO}_{3}$ [168].

\section{- Solvent Extraction and Ion Exchange for REEs Purification}

Solvent extraction (SE) and ion exchange (IX) are the conventional purification techniques in REEs processing. However, research on a complex matrix such as CFA is limited [149,152]. A study by Wang et al., (2019) [152] investigated a sequential leaching process (Figure 7) to recover REEs from CFA using $\mathrm{NaOH} / \mathrm{HCl}$. CFA was desilicated using $\mathrm{NaOH}$ to remove almost $40 \%$ of silica. The desilicated CFA was then leached in $8 \mathrm{M}$ $\mathrm{HCl}$, and $88.15 \%$ REEs were recovered. To selectively recover the REEs, IX and selective precipitation with oxalic acid are recommended as suitable techniques for high-purity REEs, but there are no details on which selective parameters to use. 


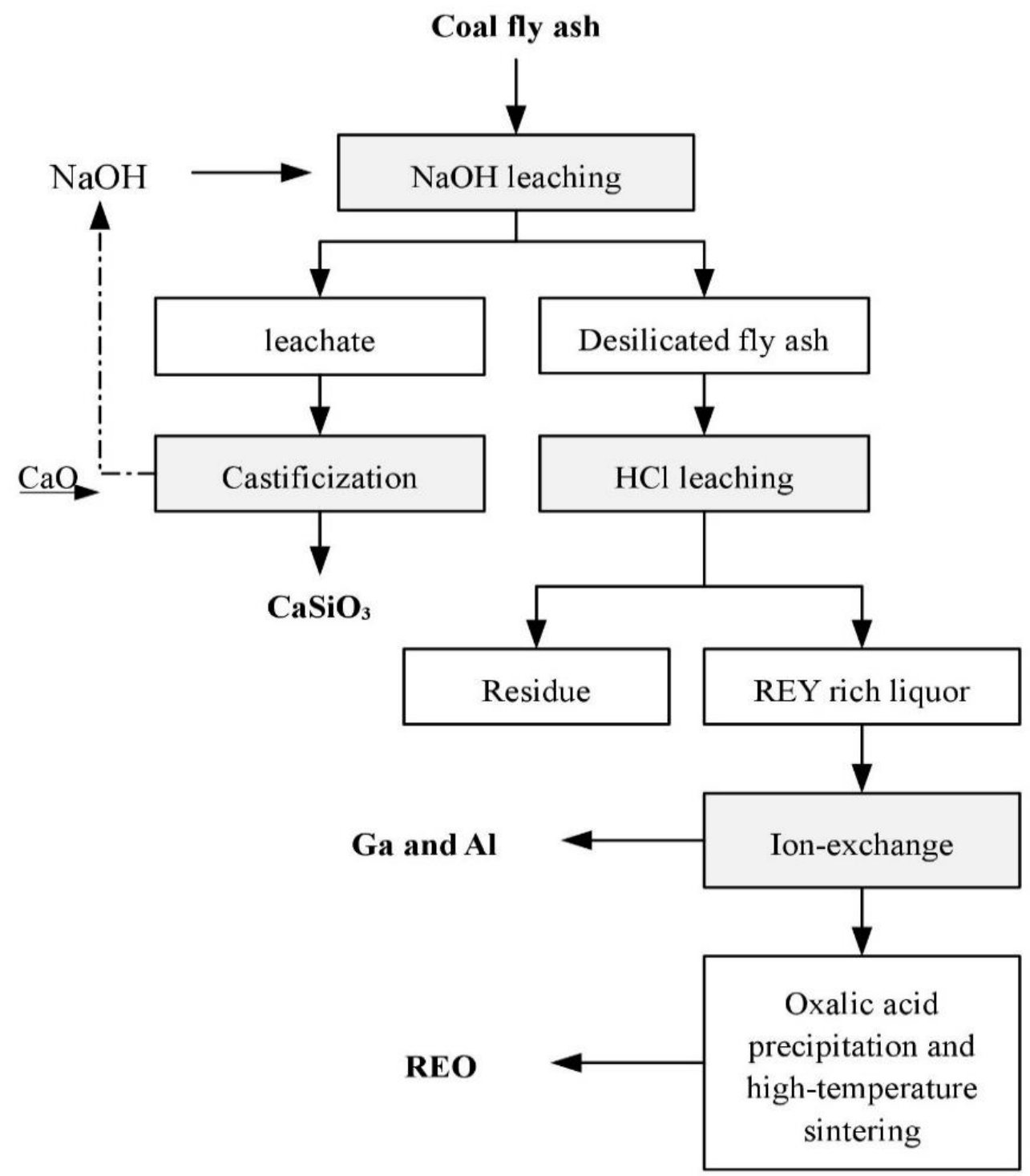

Figure 7. The extraction of the REE from CFA [157].

In a separate study, a diglycolamide-based tetra (2-ethylhexyl) diglycolamide (TEHDGA) complex was synthesised and impregnated onto Amberlite XAD-7 resin. REEs showed good adsorption on the TEHDGA-XAD-7 resin with no interference from $\mathrm{Si}, \mathrm{Al}, \mathrm{Fe}, \mathrm{Mg}$ and $\mathrm{Ca}$. The loaded REEs on the resin were eluted with $0.01 \mathrm{M} \mathrm{HNO}_{3}$, and all the rare earth metals showed similar elution behaviour [169]. However, the authors did not report the recoveries.

Table 7 summarizes different techniques used in metallurgical recovery of valuable resources from CFA, including the disadvantages and advantages of the processes. 
Table 7. Summary of the metallurgical recovery of valuable metals from CFA.

\begin{tabular}{|c|c|c|c|c|}
\hline \multicolumn{2}{|c|}{ Metallurgical Process and Conditions } & \multirow{2}{*}{$\begin{array}{c}\text { Valuables } \\
\text { Recovered (wt } \%) \\
\\
\text { Magnetite }\end{array}$} & $\begin{array}{c}\text { Note/Remark } \\
\text { Cost-effective method } \\
\text { High impurities in magnetic fraction }\end{array}$ & References \\
\hline $\begin{array}{l}\text { Magnetic } \\
\text { separation }\end{array}$ & $\begin{array}{l}\text { Dry and wet magnetic } \\
\text { separation }\end{array}$ & & $\begin{array}{l}\text { Cost-effective method } \\
\text { High impurities in magnetic fraction } \\
\text { Magnetic fraction is a potential resource as } \\
\text { iron ore and for wastewater treatment. } \\
\text { Non-magnetic fraction applicable in metal } \\
\text { recovery and construction industry }\end{array}$ & {$[113,115,118,119]$} \\
\hline \multirow[t]{2}{*}{$\begin{array}{l}\text { Direct acid } \\
\text { leaching }\end{array}$} & $\begin{array}{c}\mathrm{HCl} \text { leach }\left(150-170{ }^{\circ} \mathrm{C}\right), \\
\text { at high temperature } \\
\text { and pressure } \\
12 \mathrm{M} \mathrm{HCl} \text { at } 85^{\circ} \mathrm{C} \\
\text { for } 4 \mathrm{~h}\end{array}$ & $\begin{array}{l}\text { Al, Ti, Fe, REEs, } \\
\text { >90\% REEs, Al, Ti, } \\
\text { Fe co-extracted }\end{array}$ & $\begin{array}{l}\text { Selective process, high extraction efficiency } \\
\text { Recovery dependent on composition of CFA } \\
\text { High pressure and temperature, toxic } \mathrm{Cl}_{2} \text { gas }\end{array}$ & {$[128,129,153]$} \\
\hline & $18 \mathrm{M} \mathrm{H}_{2} \mathrm{SO}_{4}$ at $200^{\circ} \mathrm{C}$ & $84.2 \% \mathrm{Al}$ & $\begin{array}{c}\text { High alumina extraction } \\
\text { High acid consumption and leaching } \\
\text { temperature }\end{array}$ & [125] \\
\hline $\begin{array}{l}\text { Indirect } \\
\text { alkaline leach }\end{array}$ & $\begin{array}{l}\text { Pre-desilication, sinter, } \\
\text { alkaline leach }\end{array}$ & $\begin{array}{l}40 \% \mathrm{Ca}_{2} \mathrm{SiO}_{4} \\
91 \% \mathrm{Al}\end{array}$ & $\begin{array}{l}\text { Selective and reduces } \mathrm{Si} / \mathrm{Al} \text { ratio } \\
\text { Energy consumption }\end{array}$ & {$[15,53]$} \\
\hline \multirow{2}{*}{$\begin{array}{l}\text { Indirect } \\
\text { acid leach }\end{array}$} & $\begin{array}{c}\text { Sinter at } 110{ }^{\circ} \mathrm{C} \\
(3 \mathrm{~h}, \mathrm{CFA}: \mathrm{C}: \mathrm{CaO}, 5: 4: 1), \\
\text { leach with } 6.12 \mathrm{MH}_{2} \mathrm{SO}_{4} \\
\quad\left(4 \mathrm{~h} \text { at } 80^{\circ} \mathrm{C}\right)\end{array}$ & $\begin{array}{l}85 \% \mathrm{Al}, \mathrm{Ti}, \mathrm{Fe} \\
\text { co-extracted }\end{array}$ & $\begin{array}{c}\text { High extraction, low selectivity } \\
\text { Energy-intensive } \\
\text { Residue possible lightweight aggregate }\end{array}$ & [134] \\
\hline & $\begin{array}{c}\text { Roast at } \mathrm{NaOH} \text { at } \\
450{ }^{\circ} \mathrm{C} \text {, leached in } \\
3 \mathrm{M} \mathrm{HCl}\end{array}$ & $\begin{array}{l}>80 \% \text { REEs, } \mathrm{Al}, \mathrm{Ti}, \\
\text { Fe co-extracted }\end{array}$ & $\begin{array}{l}\text { High extraction, low selectivity } \\
\text { Energy-intensive }\end{array}$ & [155] \\
\hline $\begin{array}{l}\text { Acid leach- } \\
\text { sinter-acid } \\
\quad \text { leach }\end{array}$ & $\begin{array}{l}\text { Direct leaching with } 6 \mathrm{M} \\
\mathrm{H}_{2} \mathrm{SO}_{4}\left(10 \mathrm{~h}, 82^{\circ} \mathrm{C}\right) \\
\text { sintering for } 1050^{\circ} \mathrm{C} \\
(3 \mathrm{~h}, \mathrm{CFA}: \mathrm{C}: \mathrm{CaO}, 5: 4: 1), \\
\text { leaching with } 6 \mathrm{M} \\
\mathrm{H}_{2} \mathrm{SO}_{4}\left(82^{\circ} \mathrm{C}\right)\end{array}$ & $\begin{array}{l}88.2 \% \mathrm{Al}, \mathrm{Ti}, \mathrm{Fe} \\
\text { co-extracted }\end{array}$ & $\begin{array}{l}\text { High extraction, low selectivity } \\
\text { Energy-intensive } \\
\text { Residue possible lightweight aggregate }\end{array}$ & {$[20,141]$} \\
\hline \multirow{2}{*}{ Bioleaching } & $\begin{array}{l}\text { Pre-treatment in } \mathrm{HCl} \text {, } \\
\text { leaching with } \\
\text { Thiobacillus thiooxidans } \\
\text { for } 21 \text { days }\end{array}$ & $25 \% \mathrm{Al}, 22 \% \mathrm{Fe}$ & $\begin{array}{l}\text { Low extraction, low selectivity } \\
\text { Requires pre-treatment for mullite phase }\end{array}$ & [163] \\
\hline & $\begin{array}{l}\text { Roasting with } \mathrm{Na}_{2} \mathrm{CO}_{3} \\
\text { at } 850{ }^{\circ} \mathrm{C} \text { for } 2 \mathrm{~h} \\
\text { Acidithiobacillus } \\
\text { ferrooxidans }\end{array}$ & $\begin{array}{l}91.2 \% \mathrm{Al} \\
63.4 \% \mathrm{Ce}\end{array}$ & $\begin{array}{l}\text { High recovery, requires purification } \\
\text { Energy-intensive }\end{array}$ & [164] \\
\hline
\end{tabular}

\section{Challenges and Opportunities Related to CFA Sustainability}

CFA management can be classified into two categories: disposal, and beneficiation. The disposal techniques, discussed in Section 2, are no longer viable options due to enacted rules and regulations on waste management. According to Reynolds-Clausen and Singh (2017) [8], Eskom Holdings in South Africa has revised its strategy to exempt the classification of $\mathrm{CCW}$ as hazardous waste. Thus, different CCW materials will be analysed according to SANS 10234 (South African Bureau of Standards, 2008) to determine their toxic component (i.e., heavy metals). Thus far, the building and construction industry discussed in Section 4.1 does not accommodate the large quantity of CFA produced annually on its own [19]; therefore, this results in low-volume utilization. Beneficiation through highvolume and high-value-added utilization is an alternative. This review has shown that CFA activation is the alternative option in order to unlock its full potential either as an adsorbent in waste purification or in the metallurgical recovery of alumina. However, pre-treatment to activate CFA is energy-intensive and thus hinders commercial application. Additionally, pre-treatment may also results in emission of greenhouse gases. The review has also shown that utilization of CFA could result in secondary solid reside (SSR) and liquid waste, which could potentially lead to environmental pollution. The potential environmental impact of 
CFA utilization and alternative techniques, which could mitigate these effects, are discussed in details.

\subsection{The Environmental and Economic Challenges to CFA Processing}

In metallurgical recovery of alumina, processing methods that involve acidic leaching do not meet smelter-grade purity due to high co-extraction of titanium and iron into solution. Such processes require further purification such as solvent extraction, precipitation and ion exchange. This results in additional processing costs, and thus it is difficult to compete with the conventional Bayer process. With this route, poor selectivity has also been observed in REEs recovery. The SSR generated after alumina recovery has also not been studied extensively enough to be used as a basis for advocating for or against the process.

The application of CFA as a low-cost adsorbent also creates SSR. In wastewater treatment, the heavy toxic elements ( $\mathrm{Cr}$, As and $\mathrm{Ni}$ ) accumulate in SSR, and thus the disposal of these material can result in environmental pollution. While several studies have proposed the utilization of alternatives of SSR to minimize CFA disposal, only a few have evaluated the potential environmental impact of the SSR. Similarly, the liquid waste discharge generated after water treatment should align with the Waste Management Act regulation (Act. No. 59 of 2008). Therefore, the treated water should be re-used to add value, i.e., it should meet irrigation or domestic water quality standards as presented in Table 8 . Thus far, the treated AMD solutions meet irrigation standards as reviewed in Section 4.2.1. The current legislation and regulations on waste management, which aim to prevent, conserve or control environmental effects, are summarised in Table 9 . Therefore, process design is expected to comply with these policies and regulations.

Table 8. The accepted water quality range in South Africa (after $[69,170])$.

\begin{tabular}{ccc}
\hline Parameters & Irrigation Water Quality & Domestic Water Quality \\
\hline $\begin{array}{c}\text { pH } \\
\text { Sulphates }\end{array}$ & $6-8$ & $6-9$ \\
Elements (mg/L) & - & $<500 \mathrm{ppm}$ \\
(maximum/minimum) & & \\
$\mathrm{Al}$ & $<10$ & $<0.15$ \\
$\mathrm{Fe}$ & $<5$ & $<0.1$ \\
$\mathrm{Mn}$ & $<0.02$ & $<0.05$ \\
$\mathrm{Si}$ & - & - \\
$\mathrm{Ca}$ & - & $<30$ \\
$\mathrm{Na}$ & $<100$ & $<100$ \\
$\mathrm{As}$ & $<0.1$ & $<0.01$ \\
$\mathrm{Se}$ & $<0.02$ & $<0.02$ \\
$\mathrm{Cr}$ & $<0.01$ & $<0.05$ \\
$\mathrm{Cu}$ & $<0.2$ & $<1$ \\
\hline
\end{tabular}

$\overline{(-)-N o t \text { Available. }}$

Table 9. Relevant waste management policies and regulations in RSA and USA.

\begin{tabular}{|c|c|c|c|}
\hline Countries & Regulations & Content/Note & Reference \\
\hline \multirow{3}{*}{ RSA } & $\begin{array}{l}\text { Air Quality Act } \\
\text { (Act No. } 39 \text { of 2004) }\end{array}$ & $\begin{array}{l}\text { The act aims to maintain quality air and thus to prevent air pollution. Emission } \\
\text { of greenhouse gases is regulated here. Classification of CFA as hazardous waste } \\
\text { is regulated for transportation in mining site and for utilization. }\end{array}$ & \multirow{3}{*}[30,171]{} \\
\hline & $\begin{array}{l}\text { Waste Act } \\
\text { (Act No. } 59 \text { of 2008) }\end{array}$ & $\begin{array}{l}\text { The act regulates liquid and solid waste discharge limits to } \\
\text { disposal side. }\end{array}$ & \\
\hline & $\begin{array}{l}\text { National Water Act } \\
\text { (Act No. } 36 \text { of } 1998 \text { ) }\end{array}$ & Regulates water quality, water treatment and discharge to the environment & \\
\hline \multirow{3}{*}{ USA * } & Clean Air Act (1970) & Regulates toxic and heavy metals, which often affect human health. & \multirow{3}{*}[16,171]{} \\
\hline & $\begin{array}{l}\text { Resource Conservation and } \\
\text { Recovery Act } \\
\text { (act of 1976) }\end{array}$ & $\begin{array}{c}\text { Primary resources are depleting. Therefore, it is important to recycle secondary } \\
\text { resources and simultaneously reduce waste }\end{array}$ & \\
\hline & Solid waste regulation & Regulates hazardous and non-hazardous waste storage, disposal and utilization & \\
\hline
\end{tabular}




\subsection{Mitigating the Challenges in CFA Utilization}

To prevent long-term environmental challenges, process design should operate at zeroor minimal waste generation as mentioned previously. Therefore, process design should also have high capacity to recover more than one saleable product. For instance, scandium, one of the REEs, is amphoteric in nature and occurs in trace concentration compared to $\mathrm{Al}$, $\mathrm{Ti}, \mathrm{Fe}$ and $\mathrm{Si}$. Therefore, during desilication and alkaline leaching, it could be lost in silica. A potential process integration is an acid leach process (direct acid leach and sinter acid leach) where alumina, $\mathrm{Ti}, \mathrm{Fe}$ and REEs can be recovered. However, there is limited research available on the production of saleable materials other than alumina. The SSR generated could also be re-used, regenerated and recycled to minimize waste disposal.

In this study, it is observed that due to the insoluble mullite phase, the sinter-leach process is the most efficient alumina extraction process. However, the process is energy intensive, with a potential to release greenhouse gases. Alternative alumina processing technologies are necessary. Ultrasound- and microwave-assisted leaching processes are regarded as the "cleaner alternatives". In zeolite synthesis $[103,172,173]$, the application of these technologies has been researched; however, such efforts are limited in alumina production. A research study by Ma et al., (2021) [174] has shown that the microwaveassisted leaching process is efficient and can extract more than one product. In their study, CFA is baked at $280{ }^{\circ} \mathrm{C}$ to form a water-soluble godovikovite. The process can extract $>80 \%$ alumina and $>55 \%$ titanium.

\subsubsection{Value-Added Ti and Fe Recovery}

The metal oxides of Ti and Fe are attractive as catalysts for wastewater treatment $[175,176]$. The CFA leach liquor also contains metal oxide, which can further be investigated. Similarly, iron metal oxide (i.e., magnetite) is an attractive catalyst in Fenton reactions $[90,176]$. The extracted magnetic fraction could be recycled into Fenton-like catalyst.

Iron can also be recovered as coagulant. Several $\mathrm{Fe}$ and $\mathrm{Al}$ coagulants have been investigated on a laboratory scale using $\mathrm{HCl}$ and $\mathrm{H}_{2} \mathrm{SO}_{4}$ as lixiviants [177-181]. However, due to the crystalline mullite phase, it was observed that hydrothermal activation is required for high alumina $[177,178,180]$. The CFA leach liquor and the extracted iron magnetic fractions could instead be used to produce Fe-based coagulants such as $\mathrm{Fe}_{2}\left(\mathrm{SO}_{4}\right)_{3} \cdot 5 \mathrm{H}_{2} \mathrm{O}$ and $\mathrm{FeCl}_{3}$.

\subsubsection{Value Added REEs Recovery}

The production of downstream value-added REEs is important. In 2015, the South African National Mineral Research Organisation (MINTEK) launched a pilot plant for REEs aimed at separating REEs into individual elements as well as the production of other solvent-extraction-based recovery and purification applications [182]. The aim of the South African Centralized Refinery (SACREF) is to develop the full mining and manufacturing chain for REEs in South Africa. Potential deposits for such a process have been identified, such as carbonatite in Zandkopdrift and phosphogypsum waste dump and monazite from Namaqua Sand and Richards Bay [183]. The extraction of REEs from CFA could become feed concentrate material to the SACREF process. This would cut out downstream processes required for REEs purification, thereby streamlining and reducing operating steps for the REEs recycling operation, thus attaining lower OPEX and CAPEX whilst increasing capacity utilisation for existing refineries.

\subsubsection{Recycling and Regeneration of CFA Secondary Solid Residue}

For wastewater purification, this review in Section 4.2.1 shows that the SSR can be re-used as an alternative starting material for mine backfill, synthesis of geopolymer and zeolite. Such efforts can be extended to the alumina recovery residue recommended for utilization as a lightweight aggregate. Alternatively, mixing of different waste materials such as mine tailings and steel slags with CFA to adjust the $\mathrm{Si} / \mathrm{Al}$ ratio for synthesis of functionalized adsorbents could be applied [95,184]. Research by Sithole et al., (2020) [184] 
utilized CFA as a source of silica additive to supplement basic oxygen furnace slag (BOFS) in the synthesis of geopolymer to treat the South African AMD. The authors of this study reported that $99 \%$ of sulphates were efficiently recovered within 60 days.

While it is clear that CFA is a good adsorbent, limited research is available on the regeneration and recycling of the adsorbent material (CFA, zeolites and geopolymers). The adsorption and desorption of CFA was studied by Batabyal et al., (1995) [185] for organic phenol compounds in aqueous solution. The desorption process was achieved with $2 \% \mathrm{H}_{2} \mathrm{O}_{2}[185,186]$. Such research effort is not available in heavy metal recovery from the adsorbed CFA materials. The desorption process could potentially result in recovery of these heavy metals as saleable products. Potential desorption processes could be realised through chemical and thermal regeneration processes $[45,187]$.

\section{Conclusions}

This paper has reviewed and discussed current research on CFA recycling methods, the acceptability of the value-added products, challenges and opportunities in order to propose sustainable processes for CFA utilization. In this review, the following conclusions have been drawn:

Currently, there is ongoing active research to find innovative and sustainable methods of recycling CFA.

- Research on direct CFA utilization includes but is not limited to building and construction, adsorption of gaseous pollutants, wastewater treatment and zeolite synthesis.

- Research on indirect utilization of CFA includes recovery of the magnetic fraction, alumina, Ti, Fe and REEs.

Reports show that some value-added products produced from CFA material have found acceptance. This is a good indicator of sustainable methods of recycling CFA.

- Houses built in Cosmo City, South Africa, are made from geopolymers derived from CFA.

- A pilot plant designed and optimized with success for wastewater purification uses CFA derivatives.

The key challenges to the recycling of CFA are mainly environmental and economic.

- The generation of secondary solid residue and liquid waste is a threat to the environment and ecosystems.

- Current proposed processes are either energy-intensive or consume high amounts of reagents.

The principal opportunity with CFA is that it is an asset containing critical materials.

- Aluminum, titanium, iron and rare earth elements are reported to be present in CFA. If economically extracted, these constituents could be sealable value-added products, which would make CFA an attractive asset.

The proposed processes with a potential for sustainability are:

- Direct utilization in the building and construction industry.

- Recovery of $\mathrm{Al}, \mathrm{Ti}, \mathrm{Fe}$ and REEs as saleable products using an integrated process.

- Utilization of CFA (including secondary solid residue) as a low-cost adsorbent material.

Author Contributions: Conceptualization and Methodology, A.Q.V., S.N., Funding, S.N., Investigation and Writing-Original draft preparation, A.Q.V., Writing-Review and editing, S.N., L.C., A.S. All authors have read and agreed to the published version of the manuscript.

Funding: This research was funded by the National Research Foundation (NRF) and the Department of Science and Technology (DSI) of South Africa through the project with grant number 98350 .

Institutional Review Board Statement: Not applicable.

Informed Consent Statement: Not applicable.

Data Availability Statement: Not applicable. 
Conflicts of Interest: The authors declare no conflict of interest.

\section{References}

1. Harris, D.; Heidrich, C.; Feuerborn, J. Global Aspects on Coal Combustion Products. Available online: https://www.coaltrans. com/insights/article/global-aspects-on-coal-combustion-products (accessed on 5 July 2020).

2. Nicol, K. Status of Advanced Ultra-Supercritical Pulverised Coal Technology; IEA Clean Coal Centre: London, UK, 2013.

3. Wiatros-Motyka, M. An Overview of HELE Technology Deployment in the Coal Power Plant Fleets of China, EU, Japan and USA; IEA Clean Coal Centre: London, UK, 2016.

4. Ali, H.; Phoumin, H.; Weller, S.R.; Suryadi, B. Cost-Benefit Analysis of HELE and Subcritical Coal-Fired Electricity Generation Technologies in Southeast Asia. Sustainability 2021, 13, 1591. [CrossRef]

5. Sloss, L. Emissions from Coal-Fired Utilities in South Africa and Neighbouring Countries and Potential for Reduction; IEA Clean Coal Centre: London, UK, 2017; Available online: https://stg-wedocs.unep.org/bitstream/handle/20.500.11822/22223/Emissions\% 20from \%20coalfired \%20utilities\%20in\%20South\%20Africa \%20and\%20neighbouring $\% 20$ countries $\% 20$ and $\% 20$ potential $\% 20$ for\%20reduction.pdf?sequence=1 (accessed on 7 December 2021).

6. Winkler, H. Renewable Energy Policy in South Africa: Policy Options for Renewable Electricity. Energy Policy 2005, 33, 27-38. [CrossRef]

7. Eskom and Ash Management. Available online: https://www.eskom.co.za/Pages/Landing.aspx (accessed on 7 March 2021).

8. Reynolds-Clausen, K.; Singh, N. South Africa's power producer's revised coal ash strategy and implementation progress. Coal Combust. Gasif. Prod. 2019, 11, 9-11. [CrossRef]

9. European Coal Combustion Products Association. Production and Utilisation of CCPs in 2016 in Europe (EU 15). Available online: http:/ / www.ecoba.org/ ecobaccputil.html (accessed on 2 January 2022).

10. American Coal Ash Association. Coal Combustion Products Production \& Use Reports 2016. Available online: https://acaa-usa. org/wp-content/uploads/coal-combustion-products-use/2016-Survey-Results.pdf (accessed on 2 January 2022).

11. American Coal Ash Association. Coal Combustion Products Production \& Use Reports 2020. Available online: https: / acaa-usa. org/wp-content/uploads/2021/12/2020-Production-and-Use-Survey-Results-FINAL.pdf (accessed on 2 January 2022).

12. Moreno, N.; Querol, X.; Ayora, C.; Pereira, C.F.; Janssen-Jurkovicová, M. Utilization of zeolites synthesized from coal fly ash for the purification of acid mine waters. Environ. Sci. Technol. 2001, 35, 3526-3534. [CrossRef] [PubMed]

13. Ahmaruzzaman, M. A review on the utilization of fly ash. Prog. Energy Combust. Sci. 2010, 36, 327-363. [CrossRef]

14. Sibanda, V.; Ndlovu, S.; Dombo, G.; Shemi, A.; Rampou, M. Towards the utilization of fly ash as a feedstock for smelter grade alumina production: A review of the developments. J. Sustain. Metall. 2016, 2, 167-184. [CrossRef]

15. Yao, Z.; Xia, M.; Sarker, P.; Chen, T. A Review of the alumina recovery from coal fly ash, with a focus in China. Fuel 2014, 120, 74-85. [CrossRef]

16. Zhang, X. Management of Coal Combustion Wastes; IEA Clean Coal Centre: London, UK, 2014.

17. Tishmack, J.K.; Burns, P.E. The chemistry and mineralogy of coal and coal combustion products. Geol. Soc. Lond. Spec. Publ. 2004, 236, 223-246. [CrossRef]

18. Sakamoto, T.; Shibata, K.; Takanashi, K.; Owari, M.; Nihei, Y. Analysis of surface composition and internal structure of fly ash particles using an ion and electron multibeam microanalyzer. Appl. Surf. Sci. 2003, 203, 762-766. [CrossRef]

19. Wang, N.; Sun, X.; Zhao, Q.; Yang, Y.; Wang, P. Leachability and adverse effects of coal fly ash: A review. J. Hazard. Mater. 2020, 396, 122725. [CrossRef] [PubMed]

20. Shemi, A.; Ndlovu, S.; Sibanda, V.; Van Dyk, L. Extraction of alumina from coal fly ash using an acid leach-sinter-acid leach technique. Hydrometallurgy 2015, 157, 348-355. [CrossRef]

21. Campbell, A.E. Chemical, Physical and Mineralogical Properties Associated with the Hardening of Some South African Fly Ashes. Master's Thesis, University of Cape Town, Cape Town, South Africa, 1999.

22. Basu, M.; Pande, M.; Bhadoria, P.; Mahapatra, S. Potential fly-ash utilization in agriculture: A global review. Prog. Nat. Sci. 2009, 19, 1173-1186. [CrossRef]

23. Marsh, B.K.; Day, R.L. Pozzolanic and cementitious reactions of fly ash in blended cement pastes. Cem. Concr. Res. 1988, 18, 301-310. [CrossRef]

24. ASTM International. Standard Specification for Coal Fly Ash and Raw or Calcined Natural Pozzolan for Use in Concrete. Available online: www.astm.org (accessed on 2 October 2021).

25. Ash Resources. Ash Resources Fly Ash Products. Available online: https:/ / ashresources.co.za (accessed on 22 November 2020).

26. Li, J.; Zhuang, X.; Querol, X.; Font, O.; Moreno, N. A review on the applications of coal combustion products in China. Int. Geol. Rev. 2018, 60, 671-716. [CrossRef]

27. Golev, A.; Scott, M.; Erskine, P.D.; Ali, S.H.; Ballantyne, G.R. Rare earths supply chains: Current status, constraints and opportunities. Resour. Policy 2014, 41, 52-59. [CrossRef]

28. Dutta, T.; Kim, K.-H.; Uchimiya, M.; Kwon, E.E.; Jeon, B.-H.; Deep, A.; Yun, S.-T. Global demand for rare earth resources and strategies for green mining. Environ. Res. 2016, 150, 182-190. [CrossRef] [PubMed]

29. Yunusa, I.A.; Loganathan, P.; Nissanka, S.; Manoharan, V.; Burchett, M.D.; Skilbeck, C.G.; Eamus, D. Application of coal fly ash in agriculture: A strategic perspective. Crit. Rev. Environ. Sci. Technol. 2012, 42, 559-600. [CrossRef] 
30. Ndlovu, S.; Simate, G.S.; Matinde, E. Waste Production and Utilization in the Metal Extraction Industry; CRC Press: Boca Raton, FL, USA, 2017. [CrossRef]

31. Alegbe, J.; Ayanda, O.S.; Ndungu, P.; Alexander, N.; Fatoba, O.O.; Petrik, L.F. Chemical, mineralogical and morphological investigation of coal fly ash obtained from mpumalanga province, South Africa. Environ. Sci. 2018, 12, 98-105. [CrossRef]

32. Hower, J.C.; Qian, D.; Briot, N.J.; Santillan-Jimenez, E.; Hood, M.M.; Taggart, R.K.; Hsu-Kim, H. Nano-scale rare earth distribution in fly ash derived from the combustion of the fire clay coal, Kentucky. Minerals 2019, 9, 206. [CrossRef]

33. Akinyemi, S.; Gitari, W.; Akinlua, A.; Petrik, L. Mineralogy and geochemistry of sub-bituminous coal and its combustion products from mpumalanga province, South Africa. In Analytical Chemistry; Krull, I.S., Ed.; InTechOpen: Rijeka, Croatia, $2012 ;$ pp. 47-70.

34. Kelmers, A.; Canon, R.; Egan, B.; Felker, L.; Gilliam, T.; Jones, G.; Owen, G.; Seeley, F.; Watson, J. Chemistry of the direct acid leach, calsinter, and pressure digestion-acid leach methods for the recovery of alumina from fly ash. Resour. Conserv. 1982, 9, 271-279. [CrossRef]

35. Loubser, M.; Verryn, S. Combining XRF and XRD analyses and sample preparation to solve mineralogical problems. S. Afr. J. Geol. 2008, 111, 229-238. [CrossRef]

36. Ward, C.R.; French, D. Relation between coal and fly ash mineralogy, based on quantitative X-ray diffraction methods. In Proceedings of the World Coal Ash (WOCA), Lexington, KY, USA, 11-15 April 2005.

37. Sedres, G. Recovery of $\mathrm{SiO}_{2}$ and $\mathrm{Al}_{2} \mathrm{O}_{3}$ from Coal Fly Ash. Master's Thesis, University of the Western Cape, Cape Town, South Africa, 2016.

38. Mahlaba, J.S.; Kearsley, E.P.; Kruger, R.A. Physical, chemical and mineralogical characterisation of hydraulically disposed fine coal ash from Sasol synfuels. Fuel 2011, 90, 2491-2500. [CrossRef]

39. Hower, J.C.; Groppo, J.G.; Joshi, P.; Dai, S.; Moecher, D.P.; Johnston, M. Location of cerium in coal-combustion fly ashes: Implications for recovery of lanthanides. Coal Combust. Gasif. Prod. 2013, 5, 73-78. [CrossRef]

40. Kolker, A.; Scott, C.; Hower, J.C.; Vazquez, J.A.; Lopano, C.L.; Dai, S. Distribution of rare earth elements in coal combustion fly ash, determined by SHRIMP-RG ion microprobe. Int. J. Coal Geol. 2017, 184, 1-10. [CrossRef]

41. Stuckman, M.Y.; Lopano, C.L.; Granite, E.J. Distribution and speciation of rare earth elements in coal combustion by-products via synchrotron microscopy and spectroscopy. Int. J. Coal Geol. 2018, 195, 125-138. [CrossRef]

42. Yao, Z.; Ji, X.; Sarker, P.; Tang, J.; Ge, L.; Xia, M.; Xi, Y. A comprehensive review on the applications of coal fly ash. Earth-Sci. Rev. 2015, 141, 105-121. [CrossRef]

43. Ferraiolo, G.; Zilli, M.; Converti, A. Fly ash disposal and utilization. J. Chem. Technol. Biotechnol. 1990, 47, 281-305. [CrossRef]

44. Blissett, R.; Rowson, N. A review of the multi-component utilisation of coal fly ash. Fuel 2012, 97, 1-23. [CrossRef]

45. Sahoo, S. A review of activation methods in fly ash and the comparison in context of concrete strength. J. Basic Appl. Eng. Res. 2016, 3, 883-887.

46. Arp, R.; Bole-Rentel, T.; Jakuja, N. Greenhouse Gas Emissions Reductions for the South African Cement Sector. Available online: https:/ / www.wwf.org.za (accessed on 12 June 2021).

47. South African Coal Fly Ash Association (SACAA) 2021. Available online: https:/ / www.sacaa.co.za (accessed on 21 October 2021).

48. Kruger, R.A.; Krueger, J.E. Historical development of coal ash utilization in South Africa. In Proceedings of the World Coal Ash (WOCA), Lexington, KY, USA, 11-15 April 2005.

49. Müller, N.; Harnisch, J. A Blueprint for a Climate Friendly Cement Industry; WWF International: Gland, Switzerland, 2008.

50. Afrisam Institute, Cement \& Concrete. Available online: https://www.afrisam.co.za/uploads/documents/Cementitious_ materials_for_concrete.pdf (accessed on 6 March 2021).

51. Mehta, P.K. High-performance, high-volume fly ash concrete for sustainable development. In Proceedings of the International Workshop on Sustainable Development and Concrete Technology, Beijing, China, 20-21 May 2004; pp. 3-14.

52. Hemalatha, T.; Ramaswamy, A. A review on fly ash characteristics-towards promoting high volume utilization in developing sustainable concrete. J. Clean. Prod. 2017, 147, 546-559. [CrossRef]

53. Luo, Y.; Wu, Y.; Ma, S.; Zheng, S.; Zhang, Y.; Chu, P.K. Utilization of coal fly ash in China: A mini-review on challenges and future directions. Environ. Sci. Pollut. Res. 2020, 28, 18727-18740. [CrossRef]

54. Zhang, L. Production of bricks from waste materials-A review. Constr. Build. Mater. 2013, 47, 643-655. [CrossRef]

55. Ginster, M.; Matjie, R.H. Beneficial utilization of Sasol coal gasification ash. In Proceedings of the World Coal Ash (WOCA), Lexington, KY, USA, 11-15 April 2005.

56. Mr Bricks. Available online: https:/ / www.mrbrick.co.za/our-bricks/ (accessed on 7 March 2021).

57. Grice, T. Underground mining with backfill. In Proceedings of the 2nd Annual Summit œ Mine Tailings Disposal Systems, Brisbane, Carlton South, Australia, 24-25 November 1998.

58. Mashifana, T. Beneficiation of barberton gold mine tailings: The effect of fly ash on the mineralogy and micrograph. Available online: https:/ / core.ac.uk/download/pdf/161412668.pdf (accessed on 7 March 2021).

59. Gcasamba, S.; Ramasenya, K.; Diop, S.; Vadapalli, V.; Ekolu, S. Comparative Study of Two Biggest Mineral Wastes in South Africa for Mine Reclamation: A Geotechnical Study. Available online: https:/ / core.ac.uk/download/pdf/286852137.pdf (accessed on 10 December 2021).

60. Kishor, P.; Ghosh, A.; Kumar, D. Use of fly ash in agriculture: A way to improve soil fertility and its productivity. Asian J. Agric. Res. 2010, 4, 1-14. 
61. Singh, R.P.; Gupta, A.K.; Ibrahim, M.H.; Mittal, A.K. Coal fly ash utilization in agriculture: Its potential benefits and risks. Rev. Environ. Sci. Biotechnol. 2010, 9, 345-358. [CrossRef]

62. Mupambwa, H.A.; Dube, E.; Mnkeni, P.N. Fly ash composting to improve fertiliser value-A review. S. Afr. J. Sci. 2015, 111, 1-6. [CrossRef]

63. American Coal Ash Association (ACAA). Available online: https://www.acaa-usa.org/Portals/9/Files/PDFs/CaseStudies/CSFGD.pdf (accessed on 7 March 2021).

64. Davidovits, J. Geopolymer, Green Chemistry and Sustainable Development Solutions: Proceedings of the World Congress Geopolymer 2005; Geopolymer Institute: Paris, France, 2005.

65. Part, W.K.; Ramli, M.; Cheah, C.B. An overview on the influence of various factors on the properties of geopolymer concrete derived from industrial by-products. Constr. Build. Mater. 2015, 77, 370-395. [CrossRef]

66. Hardjito, D.; Wallah, S.E.; Sumajouw, D.M.; Rangan, B.V. On the development of fly ash-based geopolymer concrete. Mater. J. 2004, 101, 467-472.

67. Meesala, C.R.; Verma, N.K.; Kumar, S. Critical review on fly-ash based geopolymer concrete. Struct. Concr. 2020, 21, 1013-1028. [CrossRef]

68. Aleem, M.A.; Arumairaj, P. Geopolymer concrete-A review. Int. J. Eng. Sci. Emerg. Technol. 2012, 1, 118-122. [CrossRef]

69. Kalombe, R.M.; Ojumu, T.V.; Katambwe, V.N.; Nzadi, M.; Bent, D.; Nieuwouldt, G.; Madzivire, G.; Kevern, J.; Petrik, L.F. Treatment of acid mine drainage with coal fly ash in a jet loop reactor pilot plant. Miner. Eng. 2020, 159, 106611. [CrossRef]

70. Esterhuizen, I. Engineering News. Available online: https://www.engineeringnews.co.za/article/alternative-technology-offershousing-solution-2011-07-13 (accessed on 7 March 2021).

71. Murray and Robertson Sustainability Report. Available online: http://www.murrob.co.mz/pdf/investors/annual-integratedreports /2016/sustainability-report.pdf (accessed on 12 February 2021).

72. Querol, X.; Moreno, N.; Umaña, J.T.; Alastuey, A.; Hernández, E.; Lopez-Soler, A.; Plana, F. Synthesis of zeolites from coal fly ash: An overview. Int. J. Coal Geol. 2002, 50, 413-423. [CrossRef]

73. Margeta, K.; Logar, N.Z.; Siljeg, M.; Farkaš, A. Natural zeolites in water treatment-how effective is their use. Water Treat. 2013, 5, 81-112.

74. Mineral Commodity Summaries 2020. U.S. Geological Survey. Available online: https://pubs.usgs.gov/periodicals/mcs2020/ mcs2020.pdf (accessed on 3 June 2020).

75. South African State of Waste Report. A Report on the State of the Environment. First Draft Report. Available online: http: / / sawic.environment.gov.za (accessed on 20 March 2021).

76. Simate, G.S.; Ndlovu, S. Acid mine drainage: Challenges and opportunities. J. Environ. Chem. Eng. 2014, 2, 1785-1803. [CrossRef]

77. Fu, F.; Wang, Q. Removal of heavy metal ions from wastewaters: A Review. J. Environ. Manag. 2011, 92, 407-418. [CrossRef] [PubMed]

78. Gitari, W.; Petrik, L.; Etchebers, O.; Key, D.; Okujeni, C. Utilization of fly ash for treatment of coal mines wastewater: Solubility controls on major inorganic contaminants. Fuel 2008, 87, 2450-2462. [CrossRef]

79. Gitari, M.; Petrik, L.; Etchebers, O.; Key, D.; Iwuoha, E.; Okujeni, C. Treatment of acid mine drainage with fly ash: Removal of major contaminants and trace elements. J. Environ. Sci. Health Part A 2006, 41, 1729-1747. [CrossRef]

80. Vadapalli, V.; Klink, M.; Etchebers, O.; Petrik, L.; Gitari, W.; White, R.; Key, D.; Iwuoha, E. Neutralization of acid mine drainage using fly ash, and strength development of the resulting solid residues. S. Afr. J. Sci. 2008, 104, 317-322.

81. Madzivire, G.; Gitari, W.M.; Vadapalli, V.K.; Ojumu, T.V.; Petrik, L.F. Fate of sulphate removed during the treatment of circumneutral mine water and acid mine drainage with coal fly ash: Modelling and experimental approach. Miner. Eng. 2011, 24, 1467-1477. [CrossRef]

82. Sahoo, P.; Tripathy, S.; Panigrahi, M.; Equeenuddin, S.M. Evaluation of the use of an alkali modified fly ash as a potential adsorbent for the removal of metals from acid mine drainage. Appl. Water Sci. 2013, 3, 567-576. [CrossRef]

83. $\mathrm{Xu}, \mathrm{J} . ;$ Wan, H. Study on the treatment of acid mine wastewater by coal fly ash. In Proceedings of the International Conference on Material and Environmental Engineering (ICMAEE), Jiujiang, China, 21-23 March 2014.

84. Nyale, S.M.; Babajide, O.O.; Birch, G.D.; Böke, N.; Petrik, L.F. Synthesis and characterization of coal fly ash-based foamed geopolymer. Procedia Environ. Sci. 2013, 18, 722-730. [CrossRef]

85. Petrik, L.F.; White, R.A.; Klink, M.J.; Somerset, V.S.; Burgers, C.L.; Fey, M.V. Utilization of South African fly ash to treat acid coal mine drainage, and production of high quality zeolites from the residual solids. In Proceedings of the International Ash Utilization Symposium, Lexington, KY, USA, 20-23 October 2003.

86. Somerset, V.; Petrik, L.; Iwuoha, E. Alkaline hydrothermal conversion of fly ash precipitates into zeolites 3: The removal of mercury and lead ions from wastewater. J. Environ. Manag. 2008, 87, 125-131. [CrossRef] [PubMed]

87. Vadapalli, V.R.; Gitari, W.M.; Ellendt, A.; Petrik, L.F.; Balfour, G. Synthesis of zeolite-p from coal fly ash derivative and its utilisation in mine-water remediation. S. Afr. J. Sci. 2010, 106, 62-68. [CrossRef]

88. Madzivire, G.; Gitari, W.; Vadapalli, V.; Petrik, L. Jet loop reactor application for mine water treatment using fly ash, lime and aluminium hydroxide. Int. J. Environ. Sci. Technol. 2015, 12, 173-182. [CrossRef]

89. Mushtaq, F.; Zahid, M.; Bhatti, I.A.; Nasir, S.; Hussain, T. Possible applications of coal fly ash in wastewater treatment. J. Environ. Manag. 2019, 240, 27-46. [CrossRef]

90. Abd-Elsalam, K.A.; Zahid, M. Aquananotechnology: Applications of Nanomaterials for Water Purification; Elsevier: Amsterdam, The Netherlands, 2020. 
91. Wang, N.; Zhao, Q.; Xu, H.; Niu, W.; Ma, L.; Lan, D.; Hao, L. Adsorptive treatment of coking wastewater using raw coal fly ash: Adsorption kinetic, thermodynamics and regeneration by Fenton process. Chemosphere 2018, 210, 624-632. [CrossRef]

92. Wang, J.; Li, H.J.; Cheng, Q.K.; Yan, X.T.; Cao, A.Q.; Tan, Q.Y. Treatment of phenol wastewater with modified coal fly ash-Fenton reagent. Adv. Mater. Res. 2014, 955-959, 623-627. [CrossRef]

93. Wang, N.; Sun, X.; Zhao, Q.; Wang, P. Treatment of polymer-flooding wastewater by a modified coal fly ash-catalysed Fenton-like process with microwave pre-enhancement: System parameters, kinetics, and proposed mechanism. Chem. Eng. J. 2021, $406,126734$. [CrossRef]

94. Srinivasan, A.; Grutzeck, M.W. The adsorption of $\mathrm{so}_{2}$ by zeolites synthesized from fly ash. Environ. Sci. Technol. 1999, 33, 1464-1469. [CrossRef]

95. Zhang, L.; Ahmari, S.; Zhang, J. Synthesis and characterization of fly ash modified mine tailings-based geopolymers. Constr. Build. Mater. 2011, 25, 3773-3781. [CrossRef]

96. Niu, Y.; Zhao, Y.; Xi, B.; Hu, X.; Xia, X.; Wang, L.; Lv, D.; Lu, J. Removal of ammonium from aqueous solutions using synthetic zeolite obtained from coal fly-ash. Fresenius Environ. Bull. 2012, 21, 1732-1739.

97. Davini, P. Investigation of flue gas desulphurization by fly ash and calcium hydroxide mixtures. Resour. Conserv. Recycl. 1995, 15, 193-201. [CrossRef]

98. Telesca, A.; Marroccoli, M.; Calabrese, D.; Valenti, G.L.; Montagnaro, F. Flue gas desulfurization gypsum and coal fly ash as basic components of prefabricated building materials. Waste Manag. 2013, 33, 628-633. [CrossRef] [PubMed]

99. Brassell, J.P.; Ojumu, T.V.; Petrik, L.F. Upscaling of Zeolite Synthesis from Coal Fly Ash Waste: Current Status and Future Outlook; IntechOpen: Rijeka, Croatia, 2016.

100. Bindhu, J.; Sugunan, S. A Comparative Study of Medium and Large Pore Zeolites in Alkylation Reactions. Ph.D. Thesis, Cochin University of Science \& Technology, Kochi, India, 1998.

101. Murayama, N.; Yamamoto, H.; Shibata, J. Mechanism of zeolite synthesis from coal fly ash by alkali hydrothermal reaction. Int. J. Miner. Process. 2002, 64, 1-17. [CrossRef]

102. Hollman, G.; Steenbruggen, G.; Janssen-Jurkovičová, M. A two-step process for the synthesis of zeolites from coal fly ash. Fuel 1999, 78, 1225-1230. [CrossRef]

103. Ren, X.; Qu, R.; Liu, S.; Zhao, H.; Wu, W.; Song, H.; Zheng, C.; Wu, X.; Gao, X. Synthesis of zeolites from coal fly ash for the removal of harmful gaseous pollutants: A review. Aerosol Air Qual. Res. 2020, 20, 1127-1144. [CrossRef]

104. Ndlovu, N.Z.; Missengue, R.N.; Petrik, L.F.; Ojumu, T. Synthesis and characterization of faujasite zeolite and geopolymer from South African coal fly ash. J. Environ. Eng. 2017, 143, 04017042. [CrossRef]

105. Bandura, L.; Panek, R.; Rotko, M.; Franus, W. Synthetic zeolites from fly ash for an effective trapping of BTX in gas stream. Microporous Mesoporous Mater. 2016, 223, 1-9. [CrossRef]

106. Wdowin, M.; Franus, M.; Panek, R.; Badura, L.; Franus, W. The conversion technology of fly ash into zeolites. Clean Technol. Environ. Policy 2014, 16, 1217-1223. [CrossRef]

107. Molina, A.; Poole, C. A comparative study using two methods to produce zeolites from fly ash. Miner. Eng. 2004, 17, 167-173. [CrossRef]

108. Musyoka, N.M.; Petrik, L.F.; Balfour, G.; Gitari, W.M.; Hums, E. Synthesis of hydroxy sodalite from coal fly ash using waste industrial brine solution. J. Environ. Sci. Health Part A 2011, 46, 1699-1707. [CrossRef]

109. Musyoka, N.M.; Petrik, L.F.; Fatoba, O.O.; Hums, E. Synthesis of zeolites from coal fly ash using mine waters. Miner. Eng. 2013, 53, 9-15. [CrossRef]

110. Liu, Z.; Li, H. Metallurgical process for valuable elements recovery from red mud-A review. Hydrometallurgy 2015, 155, 29-43. [CrossRef]

111. Murtha, M.; Burnet, G. The magnetic fraction of coal fly ash: Its separation, properties, and utilization. Proc. Iowa Acad. Sci. 1978, 85, 10-13.

112. Aldrich, R.G. Separation of High Grade Magnetite from Fly Ash. U.S. Patent 4432868, 21 February 1984.

113. Shoumkova, A.S. Magnetic separation of coal fly ash from bulgarian power plants. Waste Manag. Res. 2011, 29, 1078-1089. [CrossRef]

114. Brown, J.W. Process for Recovering Magnetite from Fly Ash. U.S. Patent 4,191,336, 4 March 1980.

115. Strzałkowska, E. Morphology, chemical and mineralogical composition of magnetic fraction of coal fly ash. Int. J. Coal Geol. 2021, 240, 103746. [CrossRef]

116. Cornelius, M.-L.U.; Ameh, A.E.; Eze, C.P.; Fatoba, O.; Sartbaeva, A.; Petrik, L.F. The behaviour of rare earth elements from South African coal fly ash during enrichment processes: Wet, magnetic separation and zeolitisation. Minerals 2021, 11, 950. [CrossRef]

117. Rao, R.B.; Chattopadhyay, P.; Banerjee, G. Removal of iron from fly ash for ceramic and refractory applications. Magn. Electr. Sep. 1970, 10, 051615. [CrossRef]

118. Hill, R.O.; Raistrick, B. Process of Extraction of Aluminum Values from Coal Ash. U.S. Patent 4,243,640, 23 May 1978.

119. Lisowyj, B. Method for Extraction of Iron Aluminum and Titanium from Coal Ash. U.S. Patent 4567026, 28 January 1986.

120. Ostap, S. Control of silica in the bayer process used for alumina production. Can. Metall. Q. 1986, 25, 101-106. [CrossRef]

121. Shcherban, S.; Raizman, V.; Pevzner, I. Technologies of coal fly ash processing into metallurgical and silicate chemical products. In Proceedings of the American Chemical Society (ACS), Chicago, IL, USA, 20-25 August 1995; Volume 40.

122. Hollapa, L.; Wijk, O. Treatise on Process Metallurgy-Industrial Processes, Part A; Elsevier: Oxford, UK, 2014 ; Volume 3. 
123. Su, S.Q.; Yang, J.; Ma, H.W.; Jiang, F.; Liu, Y.Q.; Li, G. Preparation of ultrafine aluminum hydroxide from coal fly ash by alkali dissolution process. Integr. Ferroelectr. 2011, 128, 155-162. [CrossRef]

124. Authier-Martin, M.; Forte, G.; Ostap, S.; See, J. The mineralogy of bauxite for producing smelter-grade alumina. JOM 2001, 53, 36-40. [CrossRef]

125. Nayak, N.; Panda, C.R. Aluminium extraction and leaching characteristics of talcher thermal power station fly ash with sulphuric acid. Fuel 2010, 89, 53-58. [CrossRef]

126. Wu, C.; Yu, H.; Zhang, H. Extraction of aluminum by pressure acid-leaching method from coal fly ash. Trans. Nonferrous Met. Soc. China 2012, 22, 2282-2288. [CrossRef]

127. Wei, C.; Cheng, S.; Zhu, F.; Tan, X.; Li, W.; Zhang, P.; Miao, S. Digesting high-aluminum coal fly ash with concentrated sulfuric acid at high temperatures. Hydrometallurgy 2018, 180, 41-48. [CrossRef]

128. Boudreault, R.; Fournier, J.; Primeau, D. Processes for Treating Fly Ashes. U.S. Patent 9181603B2, 10 November 2015.

129. Boudreault, R.; Fournier, J.; Primeau, D.; Labrecque-Gilbert, M.-M. Processes for Preparing Alumina and Various Other Products. U.S. Patent 9382600B2, 29 June 2016.

130. Perry, R. Perry's Chemical Engineers' Handbook; McGraw-Hill: New York, NY, USA, 1984.

131. Murtha, M.J. Process for the Recovery of Alumina from Fly Ash. U.S. Patent 4397 822, 9 August 1983.

132. McDowell, W.J.; Seeley, F.G. Recovery of Aluminum and Other Metal Values from Fly Ash. U.S. Patent 4252777, 24 February 1981.

133. McDowell, W.J.; Seeley, F.G. Salt-Soda Sinter Process for Recovering Aluminum from Fly Ash. U.S. Patent 4254088, 3 March 1981.

134. Matjie, R.; Bunt, J.; Van Heerden, J. Extraction of alumina from coal fly ash generated from a selected low rank bituminous South African coal. Miner. Eng. 2005, 18, 299-310. [CrossRef]

135. Seeley, F.; McDowell, W.; Felker, L.; Kelmers, A.; Egan, B. Determination of extraction equilibria for several metals in the development of a process designed to recover aluminum and other metals from coal combustion ash. Hydrometallurgy 1981, 6, 277-290. [CrossRef]

136. Padilla, R.; Sohn, H. Sodium aluminate leaching and desilication in lime-soda sinter process for alumina from coal wastes. Metall. Trans. B 1985, 16, 707-713. [CrossRef]

137. Ding, J.; Ma, S.; Shen, S.; Xie, Z.; Zheng, S.; Zhang, Y. Research and industrialization progress of recovering alumina from fly ash: A concise review. Waste Manag. 2017, 60, 375-387. [CrossRef]

138. DeCarlo, V.; Seeley, F.; Canon, R.; McDowell, W.; Brown, K. Evaluation of Potential Processes for the Recovery of Resource Materials from Coal Residues: Fly Ash; Technical Report for Oak Ridge National Laboratory: Oak Ridge, TN, USA, 1978; pp. 13-40.

139. Bai, G.; Teng, W.; Wang, X.; Zhang, H.; Xu, P. Processing and kinetics studies on the alumina enrichment of coal fly ash by fractionating silicon dioxide as nano particles. Fuel Process. Technol. 2010, 91, 175-184. [CrossRef]

140. Wang, M.W.; Yang, J.; Ma, H.W.; Shen, J.; Li, J.H.; Guo, F. Extraction of aluminum hydroxide from coal fly ash by pre-desilication and calcination methods. Adv. Mater. Res. 2012, 396, 706-710. [CrossRef]

141. Rampou, M.; Ndlovu, S.; Shemi, A. Purification of coal fly ash leach liquor for alumina recovery using an integrated precipitation and solvent extraction process. J. Sustain. Metall. 2017, 3, 782-792. [CrossRef]

142. Muwanguzi, A.J.; Karasev, A.V.; Byaruhanga, J.K.; Jönsson, P.G. Characterization of chemical composition and microstructure of natural iron ore from muko deposits. Int. Sch. Res. Not. 2012, 2012, 174803. [CrossRef]

143. Australian Mines Atlas. Mines and Processing Centres. Available online: http://www.autralianminesatlas.gov.au/education/ fact-sheet/iron.html (accessed on 6 November 2016).

144. Øye, B.A. Carbochlorination Routes in Production of Al. Available online: https://www.sintef.no/globalassets/project/higheff/ deliverables-2018/d1.3_2018.01-chloride-process-aluminium.pdf (accessed on 20 June 2021).

145. Reynolds, J.E.; Williams, A.R. Process for Recovering Aluminum and Other Metal Values from Fly Ash. U.S. Patent 4159310, 26 June 1979.

146. Mehrotra, A.K.; Behie, L.A.; Bishnoi, P.R.; Svrcek, W.Y. High-temperature chlorination of coal ash in a fluidized bed. 1. recovery of aluminum. Ind. Eng. Chem. Process Des. Dev. 1982, 21, 37-44. [CrossRef]

147. Chaifetz, R.I.; Matusewitch, G.W.; Morton, C.C.; Phillips, J.M. Metal Chlorides and Metals Obtained from Metal Oxide Containing Materials. U.S. Patent 9315382B2, 19 April 2016.

148. Reverdy, M.; Potocnik, V. History of Inventions and innovations for aluminum production. In TMS 2020 149th Annual Meeting $\mathcal{E}$ Exhibition Supplemental Proceedings; Springer: Cham, Switzerland, 2020; pp. 1895-1910.

149. McLellan, B.; Corder, G.; Golev, A.; Ali, S. Sustainability of the rare earths industry. Procedia Environ. Sci. 2014, $20,280-287$. [CrossRef]

150. Report on Rare Earth Elements from Coal and Coal Byproducts; United States Department of Energy: Washington, DC, USA, 2017. Available online: https:/ / edx.netl.doe.gov / ree-cm (accessed on 2 February 2021).

151. Kashiwakura, S.; Kumagai, Y.; Kubo, H.; Wagatsuma, K. Dissolution of rare earth elements from coal fly ash particles in a dilute $\mathrm{H}_{2} \mathrm{SO}_{4}$ solvent. Open J. Phys. Chem. 2013, 3, 69-75. [CrossRef]

152. Cao, S.; Zhou, C.; Pan, J.; Liu, C.; Tang, M.; Ji, W.; Hu, T.; Zhang, N. Study on influence factors of leaching of rare earth elements from coal fly ash. Energy Fuels 2018, 32, 8000-8005. [CrossRef]

153. King, J.F.; Taggart, R.K.; Smith, R.C.; Hower, J.C.; Hsu-Kim, H. Aqueous acid and alkaline extraction of rare earth elements from coal combustion ash. Int. J. Coal Geol. 2018, 195, 75-83. [CrossRef]

154. Kumari, A.; Parween, R.; Chakravarty, S.; Parmar, K.; Pathak, D.D.; Lee, J.; Jha, M.K. Novel approach to recover rare earth metals (REMs) from Indian coal bottom ash. Hydrometallurgy 2019, 187, 1-7. [CrossRef] 
155. Taggart, R.K.; Hower, J.C.; Hsu-Kim, H. Effects of roasting additives and leaching parameters on the extraction of rare earth elements from coal fly ash. Int. J. Coal Geol. 2018, 196, 106-114. [CrossRef]

156. Tang, M.; Zhou, C.; Pan, J.; Zhang, N.; Liu, C.; Cao, S.; Hu, T.; Ji, W. Study on extraction of rare earth elements from coal fly ash through alkali fusion-acid leaching. Miner. Eng. 2019, 136, 36-42. [CrossRef]

157. Wang, Z.; Dai, S.; Zou, J.; French, D.; Graham, I.T. Rare earth elements and yttrium in coal ash from the luzhou power plant in Sichuan, southwest China: Concentration, characterization and optimized extraction. Int. J. Coal Geol. 2019, 203, 1-14. [CrossRef]

158. Ndlovu, S. Biohydrometallurgy for sustainable development in the African minerals industry. Hydrometallurgy 2008, 91, 20-27. [CrossRef]

159. Rasoulnia, P.; Barthen, R.; Lakaniemi, A.-M. A critical review of bioleaching of rare earth elements: The mechanisms and effect of process parameters. Crit. Rev. Environ. Sci. Technol. 2020, 51, 378-427. [CrossRef]

160. Dev, S.; Sachan, A.; Dehghani, F.; Ghosh, T.; Briggs, B.R.; Aggarwal, S. Mechanisms of biological recovery of rare-earth elements from industrial and electronic wastes: A review. Chem. Eng. J. 2020, 397, 124596. [CrossRef]

161. Sarswat, P.; Leake, M.; Allen, L.; Free, M.; Hu, X.; Kim, D.; Noble, A.; Luttrell, G. Efficient recovery of rare earth elements from coal based resources: A bioleaching approach. Mater. Today Chem. 2020, 16, 100246. [CrossRef]

162. Fass, R.; Geva, J.; Shalita, Z.P.; White, M.D.; Fleming, J.C. Bioleaching Method for the Extraction of Metals from Coal Fly Ash using Thiobacillus. U.S. Patent 5278069, 11 January 1994.

163. Seidel, A.; Zimmels, Y.; Armon, R. Mechanism of bioleaching of coal fly ash by thiobacillus thiooxidans. Chem. Eng. J. 2001, 83, 123-130. [CrossRef]

164. Fan, X.; Lv, S.; Xia, J.; Nie, Z.; Zhang, D.; Pan, X.; Liu, L.; Wen, W.; Zheng, L.; Zhao, Y. Extraction of Al and Ce from coal fly ash by biogenic $\mathrm{Fe}^{3+}$ and $\mathrm{H}_{2} \mathrm{SO}_{4}$. Chem. Eng. J. 2019, 370, 1407-1424. [CrossRef]

165. Asadollahzadeh, M.; Torkaman, R.; Torab-Mostaedi, M. Extraction and separation of rare earth elements by adsorption approaches: Current status and future trends. Sep. Purif. Rev. 2020, 50, 417-444. [CrossRef]

166. Ponou, J.; Dodbiba, G.; Anh, J.-W.; Fujita, T. Selective recovery of rare earth elements from aqueous solution obtained from coal power plant ash. J. Environ. Chem. Eng. 2016, 4, 3761-3766. [CrossRef]

167. Park, D.; Middleton, A.; Smith, R.; Deblonde, G.; Laudal, D.; Theaker, N.; Hsu-Kim, H.; Jiao, Y. A Biosorption-based approach for selective extraction of rare earth elements from coal byproducts. Sep. Purif. Technol. 2020, 241, 116726. [CrossRef]

168. Huang, C.; Wang, Y.; Huang, B.; Dong, Y.; Sun, X. The recovery of rare earth elements from coal combustion products by ionic liquids. Miner. Eng. 2019, 130, 142-147. [CrossRef]

169. Mondal, S.; Ghar, A.; Satpati, A.; Sinharoy, P.; Singh, D.; Sharma, J.; Sreenivas, T.; Kain, V. Recovery of rare earth elements from coal fly ash using TEHDGA impregnated resin. Hydrometallurgy 2019, 185, 93-101. [CrossRef]

170. Holmes, S. South African Water Quality Quidelines: Domestic Water Use, 2nd ed.; Department of Water Affairs and Forestry: Pretoria, South Africa, 1996; Volume 1.

171. Matinde, E.; Simate, G.; Ndlovu, S. Mining and metallurgical wastes: A review of recycling and re-use practices. J. S. Afr. Inst. Min. Metall. 2018, 118, 825-844. [CrossRef]

172. Aldahri, T.; Behin, J.; Kazemian, H.; Rohani, S. Synthesis of zeolite NA-P from coal fly ash by thermo-sonochemical treatment. Fuel 2016, 182, 494-501. [CrossRef]

173. Bukhari, S.S.; Behin, J.; Kazemian, H.; Rohani, S. Conversion of coal fly ash to zeolite utilizing microwave and ultrasound energies: A review. Fuel 2015, 140, 250-266. [CrossRef]

174. Ma, Y.; Stopic, S.; Xakalashe, B.; Ndlovu, S.; Forsberg, K.; Friedrich, B. A cleaner approach for recovering Al and Ti from coal fly ash via microwave-assisted baking, leaching, and precipitation. Hydrometallurgy 2021, 206, 105754. [CrossRef]

175. Zhang, W.; Zou, L.; Wang, L. Photocatalytic $\mathrm{TiO}_{2} /$ Adsorbent nanocomposites prepared via wet chemical impregnation for wastewater treatment: A review. Appl. Catal. Gen. 2009, 371, 1-9. [CrossRef]

176. Mohapatra, M.; Anand, S. Synthesis and applications of nano-structured iron oxides/hydroxides-A review. Int. J. Eng. Sci. Technol. 2010, 2. [CrossRef]

177. Fan, M.; Brown, R.C.; Wheelock, T.D.; Cooper, A.T.; Nomura, M.; Zhuang, Y. Production of a complex coagulant from fly ash. Chem. Eng. J. 2005, 106, 269-277. [CrossRef]

178. Li, L.; Fan, M.; Brown, R.C.; Koziel, J.A.; van Leeuwen, J.H. Production of a new wastewater treatment coagulant from fly ash with concomitant flue gas scrubbing. J. Hazard. Mater. 2009, 162, 1430-1437. [CrossRef]

179. Sun, T.; Sun, C.; Zhu, G.; Miao, X.; Wu, C.; Lv, S.; Li, W. Preparation and coagulation performance of poly-ferric-aluminumsilicate-sulfate from fly ash. Desalination 2011, 268, 270-275. [CrossRef]

180. Yan, L.; Wang, Y.; Ma, H.; Han, Z.; Zhang, Q.; Chen, Y. Feasibility of Fly ash-based composite coagulant for coal washing wastewater treatment. J. Hazard. Mater. 2012, 203, 221-228. [CrossRef] [PubMed]

181. Hu, K.; Zhao, Q.; Chen, W.; Tang, F.; Xu, H. Preparation and performance of fly ash-based coagulants in chemically enhanced primary treatment of domestic wastewater. Desalination Water Treat. 2016, 57, 4429-4438. [CrossRef]

182. Mintek 2016 Annual Intergated Report. Available online: https://www.mintek.co.za/wp-content/uploads/2016/10/MINTEKAnual-Report-2016.pdf (accessed on 3 April 2021).

183. Mintek Annual Integrated Report 2019/2020. Available online: https://www.mintek.co.za/wp-content/uploads/2020/11/ Mintek-Integrated-Annual-Report-2019-2020.pdf (accessed on 3 April 2021). 
184. Sithole, N.; Ntuli, F.; Okonta, F. Fixed bed column studies for decontamination of acidic mineral effluent using porous fly ash-basic oxygen furnace slag based geopolymers. Miner. Eng. 2020, 154, 106397. [CrossRef]

185. Batabyal, D.; Sahu, A.; Chaudhuri, S. Kinetics and mechanism of removal of 2, 4-dimethyl phenol from aqueous solutions with coal fly ash. Sep. Technol. 1995, 5, 179-186. [CrossRef]

186. Bada, S.; Potgieter, J.; Afolabi, A. Kinetics studies of adsorption and desorption of South African fly ash for some phenolic compounds. Part. Sci. Technol. 2013, 31, 1-9. [CrossRef]

187. Manchisi, J.; Matinde, E.; Rowson, N.A.; Simmons, M.J.; Simate, G.S.; Ndlovu, S.; Mwewa, B. Ironmaking and Steelmaking slags as sustainable adsorbents for industrial effluents and wastewater treatment: A critical review of properties, performance, challenges and opportunities. Sustainability 2020, 12, 2118. [CrossRef] 